\title{
De novo Expression of Parvalbumin in Ependymal Cells in Response to Brain Injury Promotes Ependymal Remodeling and Wound Repair
}

\author{
Viktória Szabolcsi and Marco R. Celio
}

\begin{abstract}
The calcium-binding protein parvalbumin (PV) hallmarks subpopulations of interneurons in the murine brain. We serendipitously observed the de novo expression of PV in ependymal cells of the lateral ventricle wall following in vivo lesioning and brain slicing for the preparation of organotypic hippocampal slice cultures (OHSCs). In OHSCs, de novo PV-expression begins shortly after the onset of culturing, and the number of ependymal cells implicated in this process increases with time. PVimmunopositive ependymal cells aggregate and form compact cell clusters, which are characterized by lumen-formation and beating cilia. Scratches inflicted on such clusters with a sharp knife are rapidly closed. Exposure of OHSCs to NF-KBinhibitors and to antioxidants reduces PV-expression in ependymal cells, thereby implicating injury-induced inflammation in this process. Indeed, in vivo stab injury enhances PV-expression in ependymal cells adjacent to the lesion, whereas neuraminidase denudation is without effect. PV-knock-out mice manifest an impaired wound-healing response to in vivo injury, and a reduced scratch-wound reparation capacity in OHSCs. Whole-transcriptome analysis of ependymal-cell clusters in OHSCs revealed down-regulation of genes involved in cytoskeletal rearrangement, cell motility and cell adhesion in PV-knock out mice as compared with wild-type mice. Our data indicate that the injury-triggered up-regulation of PV-expression is mediated by inflammatory cytokines, and promotes the motility and adhesion of ependymal cells, thereby contributing to leakage closure by the re-establishment of a continuous ependymal layer.
\end{abstract}

Key words: lateral ventricle, calcium-binding protein, NF-KB, inflammation, re-epithelialization

\section{Introduction}

A monolayer of multiciliated, cuboidal ependymal cells lines the brain ventricles (Bruni, 1998; Del Bigio, 2010). The ependymal cell layer of the lateral ventricles is in intimate spatial contact with the subventricular zone (SVZ), which harbors both neural stem cells (NSCs) giving rise to neuroblasts throughout life and differentiated niche cells (Zhao et al., 2008). This neurogenic niche has a finelyregulated microenvironment created by the two main niche cells, ependymal cells and astrocytes (Mirzadeh et al., 2008), which facilitates the maintenance of neurogenesis (Kazanis et al., 2008; Kokovay et al., 2008). It is characterized by a stringent spatial organization in which the ependymal cells form a pinwheel-like structure around monociliated NSCs (Mirzadeh et al., 2008). Ependymal cells also secrete substances that influence the proliferation of stem cells, such as the pigment epithelium-derived factor (PEDF) (Ramirez-Castillejo et al., 2006), noggin (Lim et al., 2000) and low-density lipoprotein-related protein 2 (LRP2) (Gajera et al., 2010). Ependymal cells could promote various functions in the NSC-niche, including detoxification and scavenging of substances in the cerebrospinal fluid (Del Bigio, 2010), modulation of ion transport and regulation of neuroblast migration (Sawamoto et al., 2006). Disruption of the ependymal-niche assembly by a removal of the lateral-membraneadaptor-protein ankyrin-3 leads to a disorganization of the 
SVZ-architecture and to a massive reduction in neurogenesis (Paez-Gonzalez et al., 2011), highlighting the impact of ependymal cells in the maintenance of stem cell proliferation and neuroblast migration. Niche ependymal cells and astrocytes were recently found to maintain a high level of plasticity and to be interconvertible by disrupting Notch- and EphB-signaling or upon niche remodeling following injury (Nomura et al., 2010). Ependymal cells express epidermal growth factor receptor (EGFR) and platelet-derived growth factor receptor alpha (PDGFR $\alpha$ ) (Danilov et al., 2009), acquire a reactive phenotype post stroke (Young et al., 2013) and during aging (Capilla-Gonzalez et al., 2014), and display similar functional properties to those shown in astrocytes, such as the presence of gap junction coupling, $K_{\mathrm{IR}}$ channels, and glutamate transporters (Liu et al., 2006).

Nevertheless, the ependymal layer, unlike other epithelial linings, is nonregenerative; ependymal cells do not proliferate in the adult brain (Spassky et al., 2005). During the process of aging or following neuraminidase-induced denudation of the ependymal layer, a limited repair response is sustained by an active SVZ-stem-cell niche in mice (Luo et al., 2008). In the aging brain, stretching of the ependymal cells (Shook et al., 2013) and the acquirement of a flattened and elongated morphology (Capilla-Gonzalez et al., 2014) has also been observed, indicating that they retain limited capacity for local remodeling.

One traditional ependymal-cell marker is S100 $\beta$, a calcium-binding protein $(\mathrm{CaBP})$ of the EF-hand family that also labels astrocytes (Cocchia, 1981). S100 $\beta$ exerts both intraand extracellular functions; intracellularly, $\mathrm{S} 100 \beta$ is a $\mathrm{Ca}^{2+}$ sensor, acts as a stimulator of cell proliferation and migration, and might be implicated in the activation of astrocytes in the course of brain damage (Donato et al., 2009). Another member of this family, parvalbumin (PV), is classically expressed in discrete populations of neurons in the brain, as well as in muscle fibers (Celio, 1990; Celio and Heizmann, 1981). No significant intrinsic PV-expression has been detected in either developing or adult glial cells, with only sporadic PVexpression reported in isolated ependymal cells of the lateral ventricle (Celio, 1990; Solbach and Celio, 1991) (see also www.brain-map.org for negative in situ hybridization results).

We report that mechanical brain injury involving the lateral ventricle wall triggers the de novo expression of PV in a large subpopulation of ependymal cells close to the site of injury in vivo and in organotypic cultures in vitro. Our data suggest that the de novo expression of PV in ependymal cells promotes their motility and adhesion, thereby facilitating wound repair and preventing the leakage of cerebrospinal fluid.

\section{Materials and Methods}

\section{Mice}

C57BL/6 (Janvier, Lyon, France), Parvalbumin-Cre/loxP-DsRedloxP-EGFP (hereafter: PV-Cre/EGFP), PV-KO, PV-KO/EGFP and
Foxj1/EGFP mice (Jackson Laboratory, Bar Harbor, ME) were used to prepare organotypic hippocampal slice cultures (Table 1). Mice expressing Cre under the parvalbumin promoter were crossed with an IRG (insulator/red/green) transgenic, double-fluorescent, Crereporter strain [B6;C3-Tg(CAG-DsRed,-EGFP)5Gae/J; Jackson Laboratory, Sacramento, CA], which has a widespread expression of a loxP-flanked red fluorescent protein variant (DsRed-Express) prior to Cre recombinase exposure, and enhanced green fluorescent protein (EGFP) following cre-mediated recombination. When bred to mice that express Cre under the parvalbumin promoter, the resulting offspring have the DsRed-Express cassette deleted in the parvalbumin-expressing cells, allowing expression of the EGFP cassette located just downstream. In a second set of experiment, PVKO/EGFP mice were generated by crossing a PV/EGFP strain (B6.Tg(Pvalb-EGFP)1Hmon) to a PV-KO strain (B6.Pvalb ${ }^{\text {tm1Swal }}$ $\mathrm{XB} 6 \mathrm{Tg}$ (Pvalb-EGFP)1Hmon). In a third set of experiments, a Foxj1/EGFP mice strain [(B6;C3-Tg(FOXJ1-EGFP)85Leo/J, Jackson Laboratory, Sacramento, CA, USA] expressing EGFP under the control of the human forkhead box J1 (FoxjI) gene promoter (Ostrowski et al., 2003) was used for organotypic cultures. All animal experiments were performed according to institutional guidelines and with the permission of the Swiss federal and cantonal committee on animal experimentation (Permission Nr: 22170 2012_26_FR and 21260 2010_26_FR).

\section{Organotypic Hippocampal Slice Cultures (OHSCs)}

Organotypic hippocampal slice cultures (OHSCs) were generated from 7 postnatal-day-old C57BL/6, PV-Cre/EGFP, PV-KO, PV-KO/ EGFP, and Foxj1/EGFP mice, using the interface method previously described (Gähwiler et al., 2001; Stoppini et al., 1991). After decapitation and excision of the brain, hippocampi were isolated manually under a stereomicroscope. Once isolated, the hippocampus was sliced to $400-\mu \mathrm{m}$-thick cross-sections with a Mcllwain Tissue Chopper (Mickle Laboratory Engineering, Goose Green, UK). The hippocampal slices were transferred onto sterile cell culture inserts of 0.4$\mu \mathrm{m}$ pore size and 30-mm diameter (Millicell $囚$, Millipore, Zug, Switzerland). In some experiments, slice cultures were also prepared-as described above-from the region of the brain containing the lateral wall of the lateral ventricle, following the isolation and removal of the hippocampi. Slice culture inserts were placed into standard sixwell plates (Fisher Scientific, Wohlen, Switzerland) in an automatic $\mathrm{CO}_{2}$ incubator (Fisher Scientific, Wohlen, Switzerland) at $37^{\circ} \mathrm{C}$ in $5 \% \mathrm{CO}_{2}$ in serum-based medium (50\% DMEM, 25\% HBSS, 25\% horse serum, $6.5 \mathrm{~g} \mathrm{~L}^{-1}$ glucose, fungizone, penicillin/streptomycin) or transferred after 2 days in a serum-free medium (Neurobasal-A medium with B27-supplement, $5 \mathrm{mM}$ Glucose, $2.5 \mathrm{mM}$ L-glutamine, Fungizone, penicillin/streptomycin). All cell culture media, reagents and supplements were from GIBCO (Life Technologies, LuBioScience, Lucerne, Switzerland). Culture medium was replaced every 2-3 days in a laminar flow. In some experiments, slice cultures were treated with different compounds added to the dissection- and culturing medium to block the effect of certain cytokines and growth factors, e.g. nuclear factor kappa B (NF-KB) activation inhibitors pyrrolidine dithiocarbamate (PDTC, $500 \mu \mathrm{M}$, Sigma-Aldrich, Buchs, Switzerland) and 6-Amino-4-(4-phenoxyphenylethylamino) 
TABLE 1: Transgenic Mice Used in the Study

\begin{tabular}{|c|c|c|}
\hline $\begin{array}{l}\text { Transgenic mice } \\
\text { name in the study }\end{array}$ & Systematic strain name & Reference \\
\hline \multirow[t]{2}{*}{ PV-Cre/EGFP } & $\begin{array}{l}\text { B6;129P2-Pvalbtm1(cre)Arbr/J X } \\
\text { B6;C3-Tg(CAG-DsRed,-EGFP)5Gae/J }\end{array}$ & $\begin{array}{l}\text { Hippenmeyer S; Vrieseling E; Sigrist M; Portmann T; } \\
\text { Laengle C; Ladle DR; Arber S. 2005. A developmental } \\
\text { switch in the response of DRG neurons to ETS } \\
\text { transcription factor signaling. PLoS Biol 3(5):e159. } \\
\text { [PubMed: 15836427] [MGI Ref ID J:100886] }\end{array}$ \\
\hline & & $\begin{array}{l}\text { De Gasperi R; Rocher AB; Sosa MA; Wearne SL; } \\
\text { Perez GM; Friedrich VL Jr; Hof PR; Elder GA. } 2008 \text {. } \\
\text { The IRG mouse: a two-color fluorescent reporter for } \\
\text { assessing Cre-mediated recombination and imaging } \\
\text { complex cellular relationships in situ. } \\
\text { Genesis 46(6):308-17. [PubMed: } 18543298 \text { ] } \\
\text { [MGI Ref ID J:137251] }\end{array}$ \\
\hline PV-KO & B6.Pvalb ${ }^{\text {tm1Swal }}$ & $\begin{array}{l}\text { Schwaller, J. Dick, G. Dhoot, S. Carroll, G. Vrbova, } \\
\text { P. Nicotera, D. Pette, A. Wyss, H. Bluethmann, } \\
\text { W. Hunziker, M.R. Celio, Prolonged contraction-relaxation } \\
\text { cycle of fast-twitch muscles in parvalbumin knockout mice, } \\
\text { Am. J. Physiol. Cell Physiol. } 276 \text { (1999) C } 395 \text { - C403 }\end{array}$ \\
\hline PV-KO/EGFP & $\begin{array}{l}\text { B6.Pvalb }{ }^{\text {tm } 1 \text { Swal } X B 6 T g} \\
\text { (Pvalb-EGFP) } 1 \mathrm{Hmon}\end{array}$ & $\begin{array}{l}\text { Schwaller B. The use of transgenic mouse models to reveal } \\
\text { the functions of Ca2+ buffer proteins in excitable cells. } \\
\text { Biochim Biophys Acta. } 2012 \text { Aug; } 1820(8): 1294-303 \text {. } \\
\text { doi: } 10.1016 / \text { j.bbagen.2011.11.008. Epub 2011 Nov } 27 \text {. } \\
\text { Review. PubMed PMID: } 22138448\end{array}$ \\
\hline Foxj1/EGFP & (B6;C3-Tg(FOXJ1-EGFP)85Leo/J & $\begin{array}{l}\text { Ostrowski LE; Hutchins JR; Zakel K; O’Neal WK. } 2003 . \\
\text { Targeting expression of a transgene to the airway surface } \\
\text { epithelium using a ciliated cell-specific promoter. } \\
\text { Mol Ther 8(4):637-45. [PubMed: 14529837] } \\
\text { [MGI Ref ID J:101822] }\end{array}$ \\
\hline
\end{tabular}

quinazoline (Act, $100 \mathrm{nM}$, Millipore, Zug, Switzerland); antioxidant $N$-acetyl-cysteine (NAC, 100-500 $\mu \mathrm{M}$, Sigma-Aldrich, Buchs, Switzerland), gamma-glutamylcysteine synthetase-inhibitor buthionine sulfoximine (BSO, 100-500 $\mu \mathrm{M}$, Sigma-Aldrich, Buchs, Switzerland) and EGFR inhibitor cyclopropanecarboxylic aciddianilinopyrimidine (50 $\mu \mathrm{M}$, Millipore, Zug, Switzerland). Slice cultures were maintainted for 1-70 days in vitro (DIV1-DIV70), then fixed for $3 \mathrm{~h}$ in $4 \%$ paraformaldehyde (PFA, Sigma-Aldrich, Buchs, Switzerland) solution in $0.1 \mathrm{M}$ Phosphate Buffer ( $\mathrm{pH} 7.4$ ) at room temperature, and processed for further experiments.

\section{Mechanical Lesion of the Ependymal Zone in OHSC}

OHSCs prepared from C57BL/6, PV-KO, PV-Cre/EGFP, and PVKO-EGFP mice $(n=3$ for each mouse line, number of slices varied from six to nine slices per mouse; i.e. $\sim 18$ scratch-wounds per mouse line were evaluated) were subjected to a manually performed mechanical lesion at the region of the ependymal zone at DIV7. The lesion was implemented under a stereomicroscope with a sharp microdissector of $100-\mu \mathrm{m}$ tip-size. Lesioned OHSCs were then placed into a
Leica DMI6000 time-lapse fluorescent microscope (Leica, Germany) equipped with an environmental chamber and images were taken every $15 \mathrm{~min}$ for a total duration of $41 \mathrm{~h}$. To assess the scratch closure time, the image series obtained in the bright field channel were used to define and measure various parameters, such as the scratch-wound area (in $\mu \mathrm{m}^{2}$ ) and the wound edge distances (in $\mu \mathrm{m}$ ) along three parallel lines drawn in the area of the scratch, perpendicular to the angle of the lesion. These parameters were measured over the whole duration of the time-lapse recording at an interval of every $3 \mathrm{~h}$ in each slice subjected to a scratch. The obtained values were normalized to the initial scratch wound area and wound edge distances measured at the "zero" time-point (the first image of the time-lapse recording after the scratch) and are presented as percentages of the initial parameters. In addition to the above mentioned parameters, the motion of individual cells expressing EGFP (in mice of PV-Cre/EGFP and PV-KO-EGFP slices) around the scratch were also measured as the distance (in $\mu \mathrm{m}$ ) between their initial position at the beginning of the time-lapse recording and their position $24 \mathrm{~h}$ later. As control, the motion of EGFP-expressing cells in unlesioned slices was measured. 


\section{Cell Death Assays}

OHSCs prepared from 7-day-old C57BL/6 and PV-KO $(n=5$ each) mice were subjected to an evaluation of cell death by assessing propidium iodide (PI) uptake combined with measurement of lactate dehydrogenase (LDH) activity in the culture medium. PI (Clontech, Mountain View, CA) was added to the culture medium at a concentration of $0.5 \mu \mathrm{g} \mathrm{mL}^{-1}$ on DIV6. At DIV7, multiple OHSCs from C57BL/6 and PV-KO ( $n=3$ each) mice were subjected to a mechanical lesion at the region of the ependymal zone as described above, while control OHSCs from C57BL/6 and PV-KO $(n=2$ each) mice remained unlesioned. PI-stained cell nuclei in the ependymal regions of all OHSCs of each animal were imaged using an inverted fluorescent microscope (Leica DMI6000) at six different time-points ( $1 \mathrm{~h}$ prior to scratching, 1, 8, 24, 48, and $72 \mathrm{~h}$ postscratching). Lactate dehydrogenase $(\mathrm{LDH})$ release to the culture medium was measured in culture wells containing OHSCs from C57BL/6 and PV-KO ( $n=3$ each) subjected to mechanical lesion in the ependymal zone at DIV7, and OHSCs from control, unlesioned mice (C57BL/6 and PV-KO, $n=2$ each). For each animal, two insert membranes-each holding 10 OHSCs-were cultured and $20 \mu \mathrm{L}$ of the culture media was obtained from each of the culture wells at six different time-points ( $1 \mathrm{~h}$ prior to scratching, 1,8 , $24,48,72 \mathrm{~h}$ post-scratching). The culture media samples were subjected in technical duplicates to a quantitation of LDH activity using the lactate dehydrogenase activity assay kit (Sigma-Aldrich, Buchs, Switzerland) following the manufacturer's instructions. In brief, $\mathrm{LDH}$ reduces $\mathrm{NAD}+$ to $\mathrm{NADH}$, which is detected by a colorimetric assay $\left(\lambda_{\max }=450 \mathrm{~nm}\right)$. Culture media samples were incubated at $37^{\circ} \mathrm{C}$ in 96 -well plates and absorbance at $450 \mathrm{~nm}$ was measured every $5 \mathrm{~min}$ by a spectrophotometric multiwell plate reader (Victor X3 by Perkin Elmer, Waltham, MA), followed by calculation of the LDH activity based on the amount of NADH generated. Fresh culture media was used as negative control.

\section{Whole-mount Immunohistochemistry}

Whole-mount immunohistochemistry was performed with well characterized antibodies to PV $(1: 1,000$, polyclonal PV-28, monoclonal PV-235, goat PV-214; Swant, Marly, Switzerland), S100ß (1:1,000, Swant, Marly, Switzerland), CD133/Prominin-1 (1:500, eBioscience, Vienna, Austria), Doublecortin (1:100, Santa Cruz Biotechnology, Heidelberg, Germany), Ki67 (1:500, NeoMarkers/Fisher Scientific, Wohlen, Switzerland), GFAP (polyclonal 1:650, Dako Schweiz AG, Baar, Switzerland and monoclonal 1:1,000, Novus Biologicals, Cambridge, UK), Nestin (1:500, Millipore, Zug, Switzerland), BrdU (1:200, Abcam, Cambridge, UK) and GFP (1:3,000; polyclonal and monoclonal from Life Technologies, Milan Analytica, Rheinfelden, Switzerland). Primary antibodies were diluted in $0.1 \mathrm{M}$ TBS pH 7.3 with $0.1 \%$ Triton X-100 and $10 \%$ bovine serum added and applied overnight at $4^{\circ} \mathrm{C}$. After thorough washing, primary antibody staining was revealed using species-specific fluorophore-conjugated secondary antibodies (Cy5 from Jackson Immuno Research/Milan Analytica, Rheinfelden, Switzerland; Alexa 488 and Alexa 568 from Life Technologies, LuBioScience, Lucerne, Switzerland). Antibodies against Ki67 and the goat-antiserum PV-214 were detected with biotinylated secondary antibodies (Jackson Jackson Immuno Research/Milan Ana- lytica, Rheinfelden, Switzerland) and revealed using Cy5 conjugated Streptavidin (Jackson Immuno Research/Milan Analytica, Rheinfelden, Switzerland).

\section{Transmission Electron Microscopy (TEM)}

OHSCs were prepared from 7 postnatal-day-old wild-type C57BL/6, PV-Cre/EGFP and PV-KO/EGFP mice, and maintained in culture for 7 , respectively 31 days. OHSCs were fixed with a solution of $4 \%$ PFA. Fixed whole-mount slice cultures were exposed to anti-PV-28 (rabbit, Swant, 1:2,000), respectively anti-GFP antibodies (mouse, Life Technologies, 1:3,000) for 3 days at $4^{\circ} \mathrm{C}$, followed by the avidin-biotin-preoxidase technique. The specimens were post-fixed in a solution containing $2.5 \%$ glutaraldehyde in $0.1 \mathrm{M} \mathrm{Na}$-cacodylate$\mathrm{HCl}$ buffer $(\mathrm{pH} 7.4)$ at room temperature for $2 \mathrm{~h}$ and thoroughly

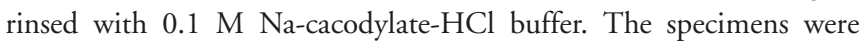
post-fixed with $1 \% \mathrm{OsO}_{4}$ and dehydrated through graded ethanol concentrations. After embedding in epon, regions containing ependymal-cell clusters were excised and affixed onto a block of resin for preparing $0.5-\mu \mathrm{m}$-thick semithin sections for light microscopic observation, followed by ultrathin sections cut with an ultramicrotome (Ultracut E, Reichert-Jung, Vienna, Austria). Ultrathin sections were stained with uranyl citrate and visualized in a transmission electron microscope (Biotwin CM-100, Philips, Eindhoven, Netherlands).

PV-KO and C57BL/6 mice ( $n=1$ each) were transcardially perfused with a solution of $2.5 \%$ Glutaraldehyde and 2\% PFA in Na-cacodylate buffer. Brains were post-fixed overnight and then cut into $100 \mu \mathrm{m}$-thick coronal sections with a vibratome (Vibratome 1000 Sectioning System, Technical Products International, St. Louis, $\mathrm{MO})$. The sections were post-fixed with $1 \% \mathrm{OsO}_{4}$ and dehydrated through graded ethanol concentrations. After embedding in epon, the medial and lateral wall of the anterior lateral ventricle and the hippocampal wall of the caudal lateral ventricle were excised and affixed onto a block of resin for preparing $0.5-\mu \mathrm{m}$-thick semithin sections for light microscopic observation, followed by ultrathin sections cut with an ultramicrotome (Ultracut E, Reichert-Jung, Vienna, Austria). Ultrathin sections were stained with uranyl citrate and visualized in a transmission electron microscope (Biotwin CM100, Philips, Eindhoven, Netherlands).

\section{Scanning Electron Microscopy (SEM)}

PV-KO and C57BL/6 ( $n=1$ each) were transcardially perfused with a solution of $2.5 \%$ glutaraldehyde and $2 \%$ PFA in Nacacodylate buffer. The lateral wall of the lateral ventricle was en-face isolated as previously described (Mirzadeh et al., 2008), followed by the isolation of the hippocampi. The specimens were post-fixed with $1 \% \mathrm{OsO}_{4}$ and dehydrated through graded ethanol concentrations. They were subjected to critical point drying with carbon dioxide and then covered with a $20 \mathrm{~nm}$-thin gold layer. The specimens were visualized in a Phenom Pro electron microscope (Phenom-World, Eindhoven, Netherlands).

\section{Primary Ependymal Cell Cultures}

Primary ependymal cell cultures were generated by mechanical isolation of the ventricular zone of the lateral ventricle walls from brains 
of newborn PV/cre/EGFP or Foxj1/EGFP mice. Mice were sacrificed by decapitation, brains were excised and the region containing the lateral ventricle wall was dissected in ice-cold PBS. Lateral ventricle wall explants were enzymatically digested at $37^{\circ} \mathrm{C}$ for $5 \mathrm{~min}$ in $0.05 \%$ Trypsin/EDTA solution (GIBCO, LuBioScience, Lucerne, Switzerland) and resuspended in pre-warmed culture medium containing DMEM supplemented with $10 \%$ fetal calf serum (GIBCO, LuBioScience, Lucerne, Switzerland) following centrifugation. Explants were mechanically dissociated by gentle pipetting through fire-polished glass pipettes of three different tip diameters. After centrifugation and washing with PBS, cells were resuspended and plated in multiwell cell culture plates (Nunc, Milan Analytica, Rheinfelden, Switzerland) at $150,000-200,000$ cells $\mathrm{mL}^{-1}$ in fresh cell culture medium.

\section{In vivo Stereotactic Lesion of the Lateral Ventricle Wall}

C57BL6 ( $n=8$, of either sex) and PV-KO/EGFP ( $n=4$, of either sex) adult mice (4- to 6-months-old) were used to perform in vivo stereotactic mechanical lesion of the lateral ventricle wall. Animals were anesthetized with Ketamine/Xylazine (100 and $10 \mathrm{mg} \mathrm{kg}^{-1}$ body weight, respectively) and the head was immobilized in a stereotactic apparatus (Kopf Instruments, Tujunga, CA). A $0.5 \mathrm{~mm}^{2}$ opening was drilled into the skull at the stereotactic coordinates and the lesion was carried out unilaterally over the left lateral ventricle with a 1 -mm-long-blade. The stereotactic coordinates of the lesion were the following: mediolateral: $+2.5 \mathrm{~mm}$, rostrocaudal: from Bregma $-1.0 \mathrm{~mm}$ to $-2.0 \mathrm{~mm}$, depth: $-3.0 \mathrm{~mm}$. After the blade penetrated the brain parenchyma, it was held in position for $5 \mathrm{~s}$, then removed. As control, one animal was shamoperated, whereas it underwent the same procedure except for penetration of the blade into the brain parenchyma. To estimate the proliferation rate in the lateral ventricle zone of the mice which underwent the in vivo injury, animals received cumulative BrdU (Sigma-Aldrich, Buchs, Switzerland) injections intraperitoneally $24 \mathrm{~h}$, resp. about $3 \mathrm{~h}$ prior to transcardial perfusion at a concentration of $100 \mathrm{mg} \mathrm{kg}^{-1}$ body weight. Lesioned and sham-operated animals were transcardially perfused with a $4 \%$ PFA solution in $0.1 \mathrm{M}$ PBS ( $\mathrm{pH} 7.4$ ) on the 7 th day post-injury, the brains were removed and post-fixed overnight at $4{ }^{\circ} \mathrm{C}$, transferred to cryoprotectant solution (18\% saccharose) and processed for cutting 30- $\mu \mathrm{m}$-thick-sections with a freezing microtome (Frigomobil, Reichert-Jung, Vienna, Austria). Immunohistochemistry on freefloating sections was performed with $\mathrm{PV}$ and $\mathrm{BrdU}$ antibodies. In another set of experiments, lesioned C57BL/6 mice $(n=3)$ were allowed a survival time of 6 weeks post-injury before sacrifice.

\section{Intraventricular Injection of Neuraminidase}

Neuraminidase from Clostridium perfringens (Roche Diagnostics, Rotkreuz, Switzerland) was dissolved in sterile $0.9 \% \mathrm{NaCl}$ solution at a concentration of $50 \mathrm{U} \mathrm{mL}^{-1}$. Young adult C57BL/6 $(n=9)$ and PV-KO $(n=9)$ male mice (3- to 4-months-old) were anesthetized with Ketamine/Xylazine (100 and $10 \mathrm{mg} \mathrm{kg}^{-1}$ body weight, respectively) and the head was immobilized in a stereotactic apparatus (Kopf Instruments, Tujunga, CA). One microliter of diluted neuraminidase $\left(0.15,1.5\right.$, and $\left.15 \mathrm{mU} \mu \mathrm{L}^{-1}\right)$ was delivered unilaterally to the rostral lateral ventricle with a stereotactically placed $5 \mu \mathrm{L}$ Hamilton microsyringe. (Coordinates: -0.2 antero-posterior, $1-\mathrm{mm}$ lateral and $2-\mathrm{mm}$ ventral relative to Bregma). Saline injection was performed in control mice. Animals were transcardially perfused on the 4th day following the intraventricular injection, the brains were cut into $40-\mu \mathrm{m}$-thickcoronal sections and immunostained for GFAP, S100ß, and PV. The rostrocaudal series of coronal sections were then processed for measurements of the lateral ventricle size (LV) and quantification of the fluorescent intensity of the immunostainings. The LV size measurement was performed on a series of 12 coronal sections_each at 240 $\mu \mathrm{m}$ from each other-at the same Bregma levels for each animal, whereas the surface of the LV (in $\mu \mathrm{m}^{2}$ ) was divided by the surface of the brain in each section. Thus, we obtained percentages over a coronal series and did the statistical analysis comparing the LV/Brain surface ratio in each treatment group. Similarly, we conducted the measurement of the fluorescent intensities in the region of the ventricles on 12 coronal sections at $240 \mu \mathrm{m}$ using ImageJ software.

\section{Visualization and Image Analysis}

Image analyses were performed with a Leica TCS SP5 confocal laser microscope (Leica, Germany), a Leica DMI6000 time-lapse fluorescent microscopy (Leica, Germany), a digital slide scanner Nanozoomer 2.0-HT (Hamamatsu Photonics France, Massy, France), respectively with transmission electron microscopy (Biotwin CM100, Philips, Eindhoven, Netherlands). Image post-processing and contrast adjustments were performed using ImageJ software, LAS AF software (Leica, Germany) and Adobe Photoshop CS2.

\section{Quantification of the Fluorescent Intensity}

To assess the fluorescent intensity of the PV-immunostaining in the ependymal-cell clusters after exposing OHSCs to compounds that modify the oxidative stress level, the Leica Application Suite Advanced Fluorescence software (LAS AF) from Leica Microsystems (Leica, Germany) was used. Out of the control and treated groups, three OHSCs were chosen for the analysis. In each slice, ependymalcell clusters were identified and several regions of interest (ROIs) with a volume of $45 \mu \mathrm{m}(x) \times 45 \mu \mathrm{m}(y)$ were fixed in the maximal-projection images recorded of ependymal-cell clusters throughout their whole volume. The mean fluorescent intensity was measured and displayed on a scale ranging from 0 to 255 , corresponding to the pixel intensities in eight-bit images. The mean values were calculated from each of these data sets per group. Statistical analyses were performed applying the Student's $t$ test to compare different treatment groups to each other. Differences were considered significant at $P<0.05$.

\section{Time-lapse Fluorescent Image Recording}

Image sequences were obtained with an inverted fluorescent microscope (Leica DMI6000) equipped with an environmental chamber at constant temperature $\left(37^{\circ} \mathrm{C}\right)$. Brightfield and fluorescent images were taken every 15-30 min for several days, respectively brightfield images continuously recorded to assess cilia beating using the LAS AF Software (Leica, Germany).

\section{Antibody Array}

The concentration of inflammatory mediators in the acutely dissected organotypic hippocampal slices was estimated with a Mouse 
Cytokine Antibody array C3 (RayBiotech, Lucerna-Chem, Lucerne, Switzerland). Hippocampi were dissected, sliced and maintained as described above in serum-free medium, followed by the collection of the medium supernatant $30 \mathrm{~min}, 2 \mathrm{~h}$ and $24 \mathrm{~h}$ after the preparation of the OHSCs. A set of cytokines was semi-quantitatively measured in the medium supernatant at different time points following the manufacturer's instructions.

\section{Gene Microarray Experiment}

OHSCs were generated from 7-day-old C57BL/6 $(n=11$, of either sex) and PV-KO mice ( $n=10$, of either sex) and maintained for 21 days in culture. On the 21 st day in vitro (DIV21) the ependymal aggregates were manually excised after identification of ependymal clusters by the presence of beating cilia under a stereomicroscope. The excised tissue was collected in $1.5 \mathrm{ml}$ Eppendorf tubes containing $350 \mu \mathrm{L}$ RNA Lysis Buffer (Qiagen, Milan Analytica, Rheinfelden, Switzerland). The extracts were disrupted and homogenized using 5-mm stainless steel beads (Qiagen) in a Tissue Lyser LT (Qiagen) for $2 \mathrm{~min}$ at $20 \mathrm{~Hz}$. The tissue lysates were processed for purification of total RNA using an RNeasy Plus Micro kit (Qiagen), following the manufacturer's instructions. The quantity of the extracted total RNA was measured with a NanoDrop 2000 spectrophotometer (Fisher Scientific, Wohlen, Switzerland) and Agilent 2100 bioanalyzer (Agilent Technologies, Palo Alto, CA). The RNA quality and RIN (RNA integrity number) were assessed with the RNA 6000 Pico Kit (Agilent). Samples with a RIN value lower than 7.6 were excluded from the experiment. Equivalent amounts of RNA were pooled from three individuals out of nine C57BL/6 mice and from three individuals out of nine PV-KO mice, resulting in three sample series, each containing 105 ng RNA, for the wild-type C57BL/6 samples (WT1-WT3) and three series for the PV-KO samples (PVKO1-PVKO3). The pooled RNA samples were stored at $-80^{\circ} \mathrm{C}$ until they were processed for the whole transcript amplification by NuGEN Ovation® Pico WTA System V2 (NuGEN Technologies, San Carlos, CA). The whole transcript amplification, labelling and gene chip hybridization on an Affymetrix Mouse Gene 1.0 ST Array (Affymetrix, Santa Clara, CA) were performed at the Genomic Technologies Facility (GTF) at the University of Lausanne, Switzerland. Hierarchical clustering was performed on fold-changes calculated from normalized expression values on $\log _{2}$ scale using the software "Expression Console" provided by Affymetrix (version 1.2.1.20). The genes with a statistically consistent fold-change were selected for subsequent analysis. Statistical analysis of the data and further clustering was performed with Multiexperiment Viewer $(\mathrm{MeV})$ v4.9 software (TM4 Microarray Software Suite, Dana-Farber Cancer Institute, Boston, MA) following the developers' instructions as previously described (Saeed et al., 2003), respectively by MetaCore software from GeneGO (Thomson Reuters, New York, NY). To discover potential diversity of biological processes between WT and PV-KO ependymal cells, Gene Set Enrichment Analysis (GSEA) (Subramanian et al., 2005) from Broad Institute of Massachusetts Institute of Technology and Harvard (Cambridge, MA) was used. Gene sets were compiled from Ncl, KEGG, PFAM, Biocarta, and GO databases. GSEA analysis was performed using gene-set permu- tations with a false discovery rate (FDR) cut-off of $5 \%$ and familywise error rate (FWER) of 5\%.

\section{Results \\ De Novo Expression of Parvalbumin in Ependymal Cells of Organotypic Hippocampal Slice Cultures (OHSCs)}

During the course of culturing organotypic hippocampal slices, we observed a de novo, ectopic expression of parvalbumin in a region corresponding to the ventricular zone (VZ) lining the lateral ventricle (Fig. 1A,B). Ependymal cells of the lateral ventricle wall which do not usually express this calcium-binding protein were found in cell-clusters corresponding to the ependymal monolayer around the edge of the slices (Fig. 1A,B), and had elongated, bipolar forms (Fig. 1C). To investigate if de novo PV-expression is restricted to the ependymal lining of hippocampal slices, we prepared slice cultures from the lateral ventricle wall covering the caudatoputamen. De novo expression of PV was found also in the ependymal-cell clusters of the lateral wall explants (Fig. 1D,D'). In both cases, PV-immunopositive cells had a radial morphology and were found to be co-labeled with the ependymal-cell marker $S 100 \beta$ (Fig. 1D,D'). The ependymal character of the PV-positive cells was confirmed by the presence of cytoplasmic lipid droplets, a cell-surface fringe of microvilli, lumen-formation and the existence of motile cilia (Fig. 1E,E'), and by S100ß-immunoreactivity (Figs. 1D,D' and 2C). PV-driven expression of EGFP was observed prompt after the onset of culturing, and the number of PV-positive cells in the cultured ependymal monolayers increased with time (Fig. $1 F)$. We observed and recorded beating cilia on the apical surface of PV/EGFP-expressing ependymal cells in both organotypic hippocampal slice cultures and in primary ependymal-cell cultures (Fig. 1G, Supporting Information Movie S1). In primary cultures, beating cilia were observed on the surfaces of the PV-positive ependymal cells as late as DIV45 (Fig. 1G, Supporting Information Movie S1). Beating cilia were also present on other cells which did not express PV-driven EGFP. To investigate whether the up-regulation of PV influences cilia movement, we quantified the cilia beating frequency between ependymal cells that expressed PV-driven EGFP and that were PV-negative. We found a beating frequency of $7.81 \mathrm{~Hz} \pm 2.81$ in PV + cells and $8.28 \mathrm{~Hz} \pm 2.06$ in PV-cells, an insignificant difference $(P=0.77)$ (Fig. $1 \mathrm{H})$. Thus, we assume that the presence of PV in ependymal cells does not influence the cilia beating frequency.

\section{PV-immunoreactive Ependymal Cells are Positive for Foxj1, S100ß, and CD-133}

Under physiological conditions, ependymal cells are considered to be post-mitotic and quiescent (Spassky et al., 2005). However, they have been described to undergo dedifferentiation in 

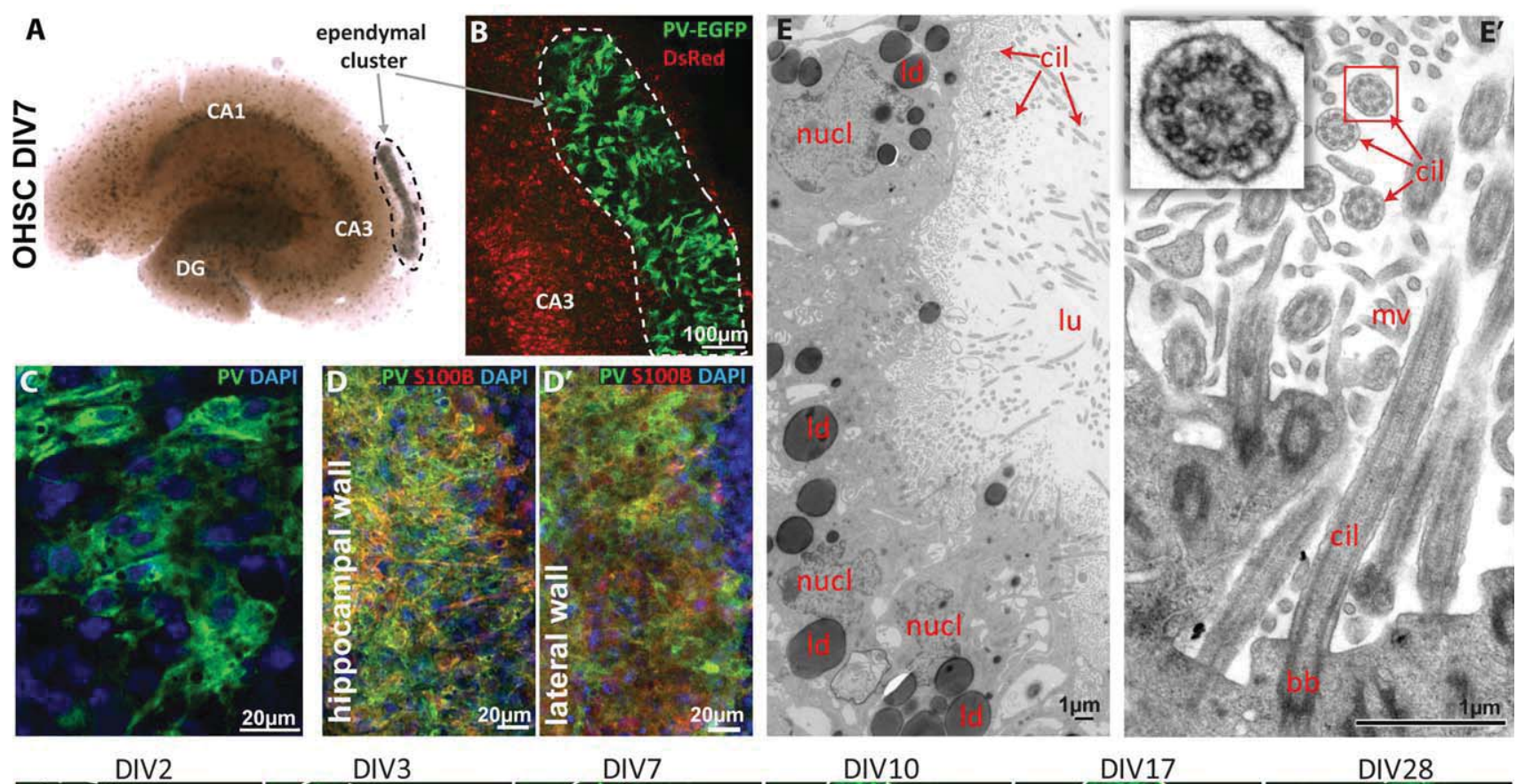

DIV17
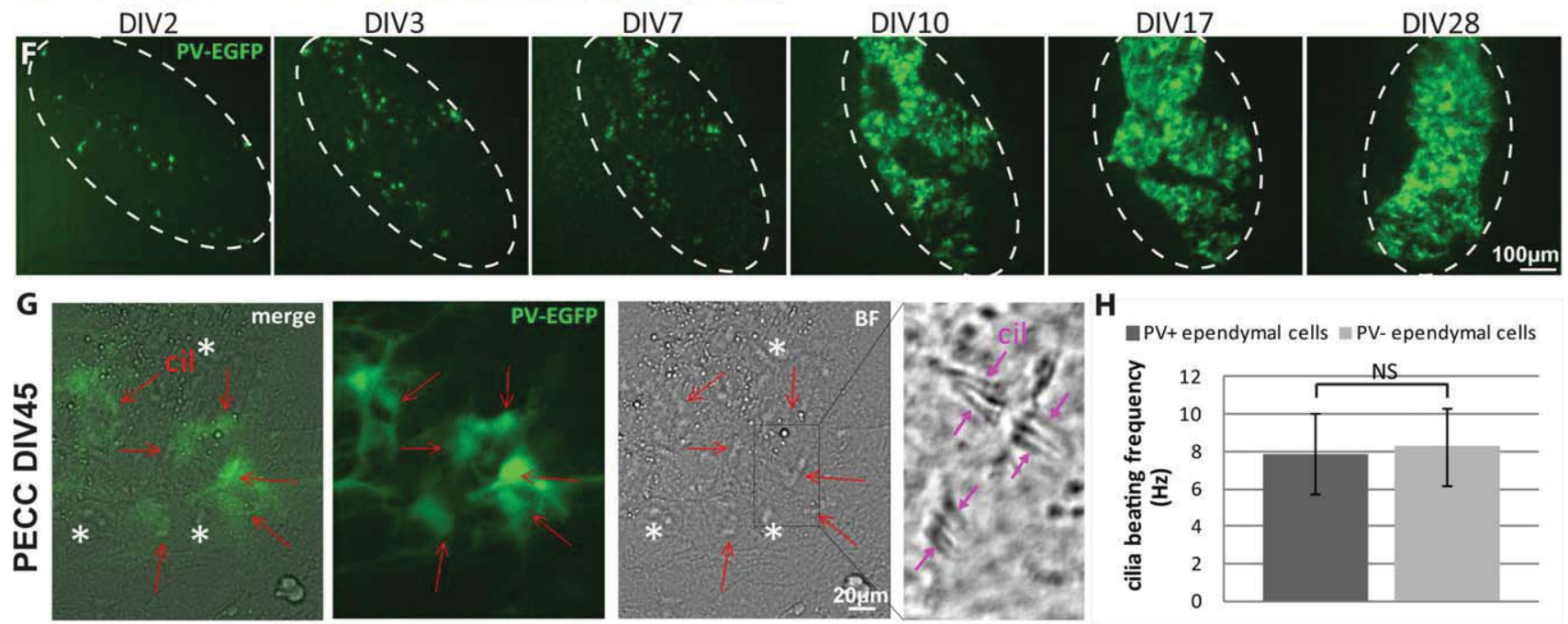

H

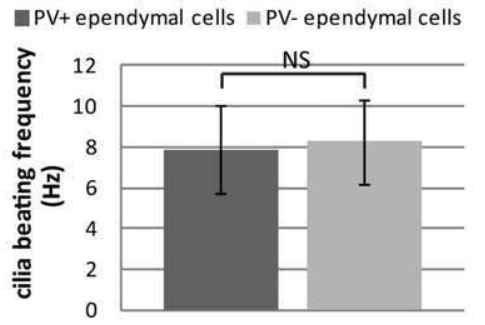

FIGURE 1: De novo parvalbumin-expression in ependymal cells in organotypic hippocampal slice culture (OHSC) and dissociated primary ependymal-cell culture (PECC). (A) Overview image of a DIV7-OHSC after epon-embedding and $1 \% \mathrm{OsO}_{4}$ treatment. Dashed outline indicates the localization of the ependymal-cell cluster. (B) Confocal z-stack projection of an ependymal-cell cluster (marked by dashed outline) at the ventricular zone (VZ) region in an OHSC specimen from a PV-Cre/EGFP mouse fixed at DIV7. PV-expressing cells are EGFP-positive, whereas cells not expressing PV are DsRed-positive. (C) Confocal z-stack projection of PV-positive ependymal cells revealed by PV-immunohistochemistry and DAPI staining in OHSC of a C57BL/6 mouse at DIV7. Cells form compact cell aggregates, occasionally extending their cytoplasmic processes over the cell island. $\mathrm{Bi}$ - and multipolar cell shapes with elongated nucleus and cytoplasmic processes are visible. (D-D') PV is expressed in ependymal-cell clusters of both the hippocampal wall and the lateral wall of the lateral ventricle in DIV7 C57BL/6 slice cultures. Ependymal cells have a radial morphology and are co-labeled with S100ß. (E-E') Transmission electron micrographs of ependymal-cell clusters of OHSCs of a C57BL/6 mouse fixed on DIV7 reveal ependyma-specific cell organelles, such as lipid droplets, cilia, basal bodies and microvilli, and lumen-formation. (F) Live fluorescent time-lapse image sequence of OHSCs from a PV-Cre/EGFP mouse showing increasing number of PV-expressing ependymal cells at six time points from DIV2 until DIV28. Dashed ellipses indicate ependymal-cell clusters. (G) Live fluorescent and bright field images of primary ependymal cell culture from a PV-Cre/EGFP mouse at DIV45. A subset of ependymal cells express PV-driven EGFP, display long cytoplasmic processes and possess motile cilia (red arrows). The boxed area is shown at higher magnification to visualize the motile cilia bundles (pointed at by pink arrows) at the apical surface of ependymal cells. White stars mark motile cilia at the surface of PV-EGFP negative ependymal cells. (H) The graph shows that the cilia beating frequency of PV-expressing and PV-negative ependymal cells does not differ significantly. Error bars show the standard deviation. (PECC: primary ependymal cell culture, OHSC: organotypic hippocampal slice culture, DG: dentate gyrus, cil: cilium, bb: basal body, mv: microvilli, nucl: nucleus, Id: lipid droplet, lu: lumen). 

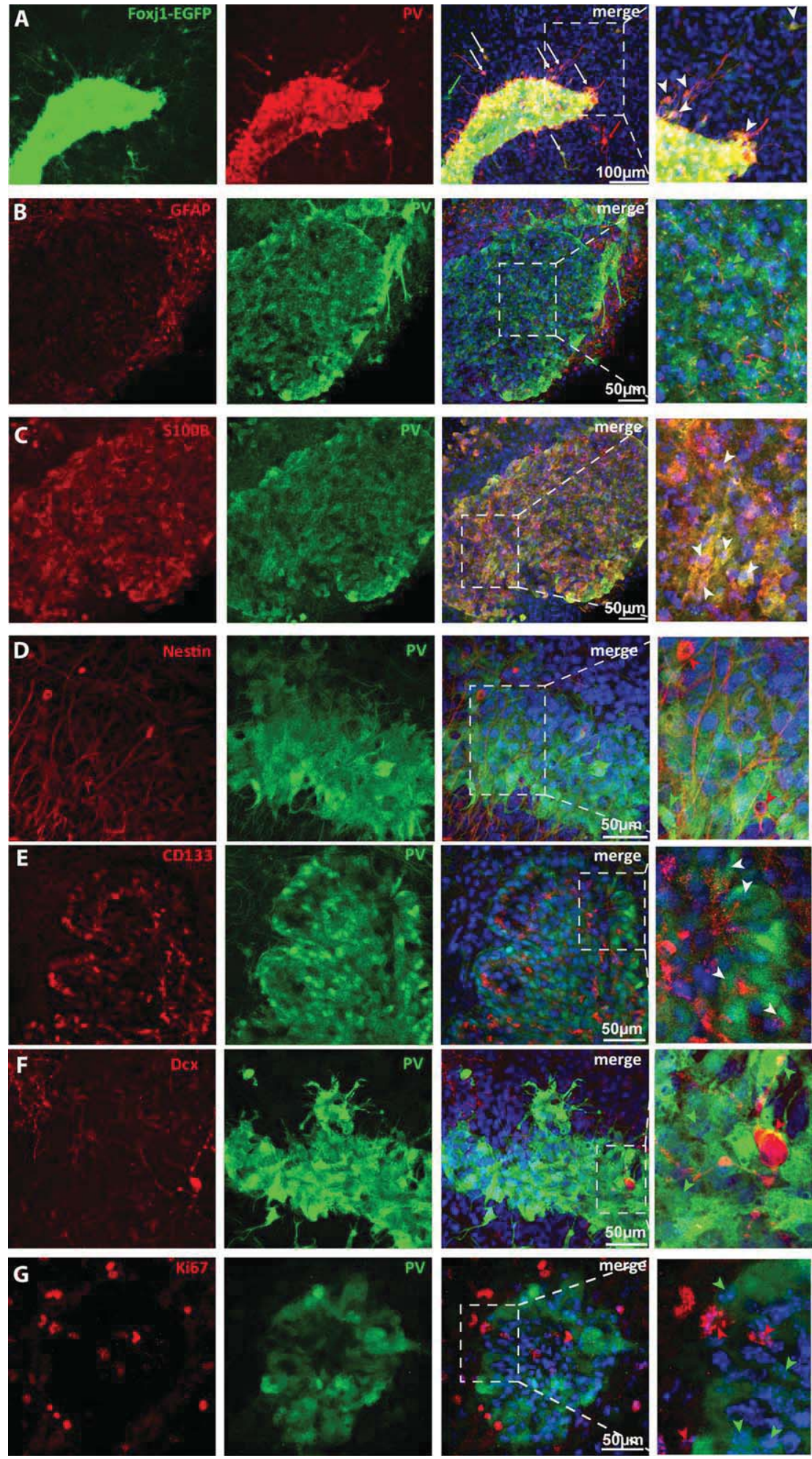

FIGURE 2: PV-positive cells in the ependymal clusters are Foxj1-, S100ß-, and CD133-positive and neural progenitor and precursor cells are intermingled between them. (A) Confocal z-stack projection of PV-immunohistochemistry on OHSCs of a Foxj1/EGFP mouse at DIV11 reveals a Foxj1/EGFP positive ependymal-cell cluster co-labeled with PV-antibody. Most of the cells emerging from the cell island are double-labeled (white arrows and arrowheads), although some Foxj1/EGFP positive cells are PV-negative (green arrows) and some PV-positive cells are Foxj1/EGFP negative (red arrows). (B-G) are confocal z-stack projections of immunostainings of ependymal-cell islands in OHSC of C57BL/6 mice at DIV7. (B) GFAP is not co-labeled with PV (green arrowheads) in the same cells. (C) S100ßimmunostaining co-labels PV-immunopositive cells in the ependymal-cell clusters (see white arrowheads in the inset on the right). (D) Nestin-immunopositive cell bodies (red arrowheads) and processes are intermingled between PV-immunopositive cells (green arrowheads), but no double-labeled cells were detected. (E) CD133-immunostaining co-labels some PV-immunopositive cells in the ependymal-cell clusters (see white arrowheads). (F) Doublecortin-immunostaining (Dcx) reveals a Dcx-positive cell (red arrowhead) and its processes intermingled between PV-positive ependymal cells (green arrowheads), however, no co-expression can be observed. (G) Ki67-immunostaining reveals cell nuclei in the active phases of the cell cycle. Ki67-stained cell nuclei (red arrowheads) are found around PV-positive ependymal cells. No labeling was detected in the cell nuclei of PV-positive cells (green arrowheads), suggesting that PVpositive cells were not actively proliferating at the time of fixation at DIV7. 
response to strong stimuli such as mechanical injury (Carlen et al., 2009). Indeed, a subpopulation of ependymal cells expresses Prominin-1/CD133-a stem-cell marker (Coskun et al., 2008). In OHSCs, we observed morphological features similar to those described in "reactive" ependymal cells, namely, the acquirement of radial and bipolar forms (Gregg and Weiss, 2003). The remarkable fate plasticity of ependymal cells (Nomura et al., 2010) gives rise to questions concerning the origin of PV-expressing ependymal cells, as well as to their potential to generate new cells and to contribute to the process of niche-remodeling that follows tissue damage in OHSCs and in vivo.

Foxj1-driven EGFP-expression in the brain is restricted to ependymal cells and to a subset of progenitor cells derived from the ventricular zone (Jacquet et al., 2009; Ostrowski et al., 2003). Foxj1/EGFP-expressing murine pups were used to study the morphology and the pattern of PV-expression in ependymal cells of OHSCs. In the ependymal clusters, colabeling for Foxj1/EGFP and PV was observed in the ependymal cells themselves, as well as in several cells that lay close to the ependymal nest (Fig. 2A). The cells surrounding the ependymal clusters manifested an elongated form and protruded long cytoplasmic processes, which projected radially from the nest. Most of the cells co-expressed Foxj1/EGFP and PV (Fig. 2A). However, amongst the cells surrounding the ependymal clusters, a few of the Foxj1/EGFP-expressing ones were not PV-positive, suggesting that only a subpopulation of the ependymal cells produce the CaBP.

To delineate the characteristics of the ependymal-cell clusters, DIV7 OHSCs were subjected to co-immunostaining for the astrocyte marker GFAP and the ependymal marker S100ß. Immunoreactivity for GFAP did not coincide with the PV/EGFP-expressing cells (Fig. 2B), whereas that for S100ß did (Fig. 2C). This finding confirms that the PVpositive cells in the ventricular niche are a subset of ependymal cells.

\section{Increase in the Number of PV-positive Cells Reflects De novo PV-synthesis-Not Cell Proliferation}

To investigate if PV-expressing ependymal cells retain proliferative or progenitor-like properties, immunostaining for Nestin (a marker of neural stem cells), Prominin-1/CD133 (a marker of ependymal cells and progenitors in the VZ), Doublecortin (a marker of neural progenitors and of migrating neuroblasts) and Ki67 (a marker of cell proliferation) was performed. Immunoreactivity for nestin was disclosed in several cell bodies and in cytoplasmic processes that ran between the PVpositive ependymal cells. However, none of the nestin-positive cell bodies co-expressed PV (Fig. 2D). Although ependymal cells with a certain stem-cell capacity have been shown to express CD133 (Coskun et al., 2008), their identity remains controversial (Chojnacki et al., 2009; Kriegstein and AlvarezBuylla, 2009). Immunostaining for CD133 was observed in the PV-positive cells (Fig. 2E), thereby confirming their ependymal phenotype. The neuroblast marker Doublecortin was not co-expressed with PV (Fig. 2F). However, as was observed for nestin-immunoreactivity, long neural processes coursing between the PV-positive ependymal cells were labeled. Ki67 is a marker of cell nuclei in the active phases of the cell cycle, thus it marks cells that were proliferating at the time of fixation of the tissue. Immunostaining for Ki67 revealed most of the PV-positive ependymal cells in the clusters to be nonproliferative at DIV7, at the time-point of the fixation (Fig. $2 \mathrm{G})$. However, owing to the dense organization of the PVpositive ependymal cells, which rendered difficult an identification of their borders, some degree of co-localization may not be categorically excluded. Additionally, we cannot exclude that PV-positive ependymal cells might have been proliferating earlier than DIV7, as Ki67 marks only the cell nuclei that are currently in the active phases of the cell cycle. But even if a few of the ependymal cells in the OHSCs had undergone division, the hypothetically low proliferation rate could not have accounted for the massive increase in the number of the PV-positive ependymal cells. Hence, we believe that the increase in the number of the PV-positive ependymal cells that was observed in the OHSCs reflects the de novo expression of the $\mathrm{CaBP}$ in a continuously recruited population rather than proliferative activity.

\section{The Up-regulation of Parvalbumin in Ependymal Cells is Injury-related and Facilitates Gap Closure After a Scratch-Wound Inflicted to OHSC}

To investigate the mechanism whereby PV-expression is triggered in ependymal cells, OHSCs of PV-Cre/EGFP-mice were subjected to a scratch-wound assay. Ependymal-cell aggregates of DIV7 OHSCs were mechanically injured with the tip of a sterile microdissector and PV-driven EGFPexpression was monitored by time-lapse microscopy for $41 \mathrm{~h}$ and followed up for 7 consecutive days. Twenty-nine h after lesioning, cells adjacent to the site of injury manifested increased EGFP-fluorescence intensity than did those at some distance from the lesion (Fig. 3A). This finding suggests that the mechanical lesioning of the cells can directly induce an up-regulation of the parvalbumin gene. Seventy-two hours after scratching, the cells adjacent to the lesion still showed more intense EGFP-expression than did those further away from it. Six, resp. seven days after scratching, EGFPfluorescence was homogenously distributed throughout the ependymal cell mass, as was the case prior to wounding (Fig. 3A). Our findings indicate that the de novo expression of PV that was observed in OHSCs might be a direct consequence of the mechanical lesion that occurs during their preparation. 

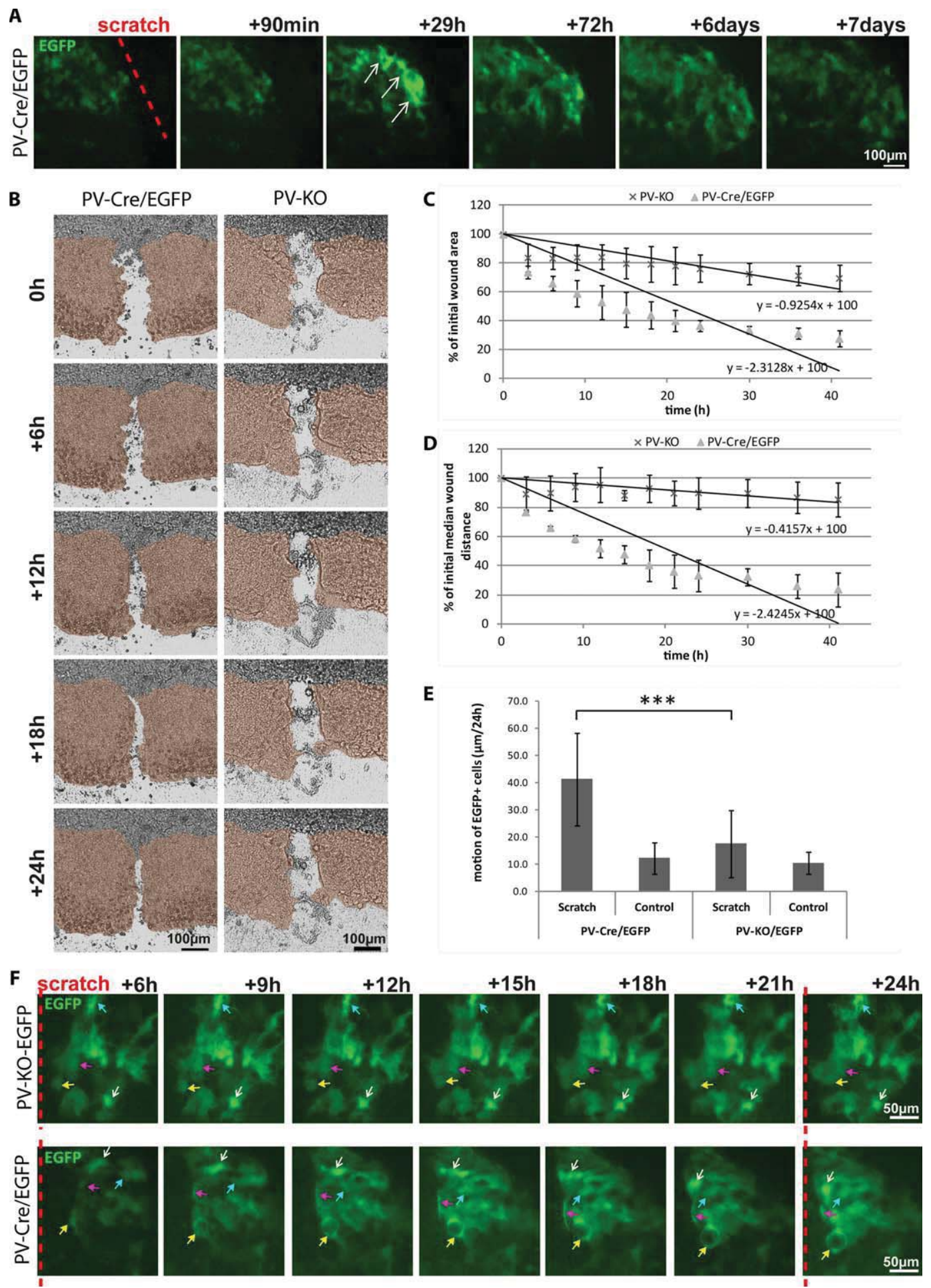

FIGURE 3: Mechanical lesion of ependymal-cell clusters in OHSCs induces PV-upregulation in ependymal cells adjacent to the lesion. (A) Time-lapse fluorescent image sequence of scratch-wound experiments in ependymal-cell clusters in PV-Cre/EGFP OHSCs shows increase in PV-driven EGFP-expression in the cells adjacent to the scratch. About $29 \mathrm{~h}$ following the scratch, EGFP-expression is visibly stronger in cells at the two edges around the lesion. At $72 \mathrm{~h}$ after scratch, EGFP-expression is still stronger around the mechanical lesion; whereas 6 and 7 days post-scratch, EGFP-expression appears more homogeneous. (B) Time-lapse bright field image sequence of PV-Cre/EGFP and PV-KO ependymal scratches over $24 \mathrm{~h}$ reveal that PV-Cre/EGFP scratch rims approach each other more rapidly than their PV-KO counterparts. Ependymal-cell clusters are pseudocolored with orange; the background caused by the cell culture insert membrane was subtracted in favor of a better visualization. (C and D) The scratch gap closing time of PV-Cre/EGFP and PV-KO ependymal scratches are presented as percentages of the initial wound area (C) and as percentages of the initial median distance between the wound rims (D). The speed of the regression is shown as a trendline with the corresponding equations. The wound area is decreasing consistently in both PV-Cre/EGFP and PV-KO lesions, although more rapidly in PV-Cre/EGFP (C) $(P=0.01$ at $6 \mathrm{~h}$ and $<0.005$ starting from $9 \mathrm{~h})$. Likewise, the median wound distance shows a faster decreasing tendency in PV-Cre/EGFP as compared with PV-deficient ependymal-cell clusters $(D)(P<0.05$ at $3 \mathrm{~h}$ and $<0.001$ starting from $6 \mathrm{~h}$ ). (E) The graph shows that the motion of the EGFP+ cells over $24 \mathrm{~h}$ around the wound rims is higher following the scratch in PV-Cre/EGFP than in PV-KO/EGFP mice. The motion of unlesioned EGFP+ cells (=control cells) of both PV-Cre/EGFP and PVKO-EGFP were also measured: no significant difference can be found between their cell motility. (F) Time-lapse image sequences show the movement of EGFP+ ependymal cells over $24 \mathrm{~h}$ next to a scratch (the position of the scratch is marked by dashed red line). PV-Cre-EGFP+ cells (tracked with colored arrow) show considerable cell shape alterations and move closer to the scratch line while their PV-KO/EGFP+

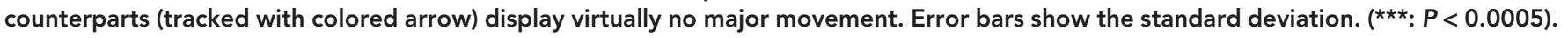


Next, we compared the kinetics of wound closure following a mechanical scratch at the continuous ependymal-cell cluster in OHSCs of C57BL/6 $(n=3)$, PV-Cre/EGFP $(n=3)$, PV-KO $(n=3)$, and PV-KO-EGFP $(n=3)$ mice. The success rate for scratch closure in the $\mathrm{C} 57 \mathrm{BL} / 6$ and PV-Cre/ EGFP ependymal cell clusters was over $80 \%$, whereas a low percentage of $30 \%$ was observed in PV-KO ependymal clusters (examples shown in Fig. 3B). Quantification of the wound area over time showed that the PV-KO lesions indeed remained larger than those of the PV-Cre/EGFP lesions (69.6\% of the initial wound area $\pm 9.1 \%$ for PV-KO compared with $27.7 \% \pm 5.8 \%$ for PV-Cre/EGFP after 41 h, Fig. $3 \mathrm{C})$. The scratch-wound area was significantly larger in PV$\mathrm{KO}$ ependymal-cell clusters as compared with their wild-type counterparts starting at $6 \mathrm{~h}$ post-scratch $(P=0.01)$, and the difference increased over time $(9 \mathrm{~h}$ post-scratch $P=0.001$, from $12 \mathrm{~h}$ until $41 \mathrm{~h}$ post-scratch $P<0.001)$. This phenomenon was even more prominent when we examined the distance between wound edges over time: the median wound edge distance was $85.2 \% \pm 11.7 \%$ for PV-KO and $23.7 \% \pm$ $11.6 \%$ for PV-Cre/EGFP after $41 \mathrm{~h}$ (Fig. 3D). The wound edge distance in PV-KO ependymal-cell clusters was significantly larger as prompt as $3 \mathrm{~h}$ post-scratch $(P=0.02)$, and similarly to the wound area, the difference increased over time (at $6 \mathrm{~h}$ post-scratch $P=0.0008$, from $9 \mathrm{~h}$ post-scratch until $41 \mathrm{~h}$ post-scratch $P<0.0001$ ). Thus, we conclude that in OHSCs a mechanically disrupted ependymal cell layer has the capacity of re-establishing a continuous layer, and this capacity is impaired in PV-deficient ependymal cells.

Next, we examined the motility of PV-positive ependymal cells around the lesion based on their PV-driven EGFP expression, and compared it to that of PV-KO-EGFP cells. This strain cannot transcribe PV: $85 \%$ of the Pvalb-genecoding sequence is replaced with the phosphoglycerate-kinase (PKG) neo-cassette (Schwaller et al., 1999); the activity of the promoter is, in contrast, unaffected and drives the expression of EGFP. Hence, using this murine strain, PV-deficient cells can be visualized and followed-up. Generally, in PV-Cre/ EGFP slices, EGFP+ cells around the lesion showed a remarkable motility and cell shape alteration in contrast to the PV-deficient ones (Fig. 3F). We measured the absolute motion of EGFP+ cells around the scratch from the startpoint of the lesion until $24 \mathrm{~h}$ later, and we found that the ependymal cells expressing PV moved considerably more than those lacking PV (Fig. 3E,F). PV-Cre/EGFP ependymal cells around the lesion moved $41.3 \mu \mathrm{m} \pm 17 \mu \mathrm{m}$ in $24 \mathrm{~h}$, while PV-deficient cells moved only $17.5 \mu \mathrm{m} \pm 12.3 \mu \mathrm{m}(P<$ 0.00001). In comparison, the motion of EGFP + cells of the control, unscratched ependymal-cell clusters was around 12.2 $\mu \mathrm{m} \pm 5.7 \mu \mathrm{m}$ in PV-Cre/EGFP ependymal clusters and $10.48 \mu \mathrm{m} \pm 4.1 \mu \mathrm{m}$ in the PV-KO-EGFP ones (Fig. 3E), moderately higher in PV-expressing ependymal cells, although not significantly $(P=0.1)$. This suggests that PV-expressing ependymal cells have an enhanced motility following the disruption of the continuous layers. PV-deficient ependymal cells, in contrast, have a significantly more restricted motility.

Next, we addressed the question if the impairment seen in the scratch-wound closing kinetics of the ependymal-cell clusters of PV-deficient slices could be caused by a more extensive degree of cell death following scratching compared with their wild-type counterparts. We assessed the degree of cell death by two independent approaches suggested by previous studies in organotypic slice culture systems, namely quantitation of lactate dehydrogenase (LDH) release into the medium and propidium iodide (PI) uptake (Lossi et al., 2009). We measured the baseline degree of cell death $1 \mathrm{~h}$ prior to scratching in all the inserts and slices in both WT and PV-KO $(n=3,10$ OHSCs/well, total number of scratched OHSCs $=60$ for each), then repeated measurements $1 \mathrm{~h}, 8 \mathrm{~h}, 24 \mathrm{~h}, 48 \mathrm{~h}, 72 \mathrm{~h}$ and 1 week after scratching and compared the values to unlesioned control $(n=2,10$ OHSCs/well, total number of control OHSCs $=40$ for each WT and PV-KO). The quantitative approach of LDH activity measurement revealed significantly increased $\mathrm{LDH}$ efflux $(P<0.05$, Student's $t$ test $)$ from scratched ependymal-clusters in both WT and PV-KO at $1 \mathrm{~h}$ post-scratch $\left(5.6 \mathrm{mU} \mathrm{mL}^{-1}\right.$ $\pm 0.9 \mathrm{mU} \mathrm{mL}^{-1}$ vs. $1.7 \mathrm{mU} \mathrm{mL}^{-1} \pm 0.5 \mathrm{mU} \mathrm{mL}^{-1}$ in WT; $5.3 \mathrm{mU} \mathrm{mL}^{-1} \pm 0.4 \mathrm{mU} \mathrm{mL}^{-1}$ vs. $2.0 \mathrm{mU} \mathrm{mL}^{-1} \pm$ $0.5 \mathrm{mU} \mathrm{mL}^{-1}$ in PV-KO), $8 \mathrm{~h}$ post-scratch $\left(7.0 \mathrm{mU} \mathrm{mL}^{-1}\right.$ $\pm 0.8 \mathrm{mU} \mathrm{mL}^{-1}$ vs. $3.2 \mathrm{mU} \mathrm{mL}^{-1} \pm 0.1 \mathrm{mU} \mathrm{mL}^{-1}$ in WT; $7.5 \mathrm{mU} \mathrm{mL}^{-1} \pm 1.0 \mathrm{mU} \mathrm{mL}^{-1}$ vs. $2.2 \mathrm{mU} \mathrm{mL}^{-1} \pm$ $0.5 \mathrm{mU} \mathrm{mL}^{-1}$ in PV-KO), $24 \mathrm{~h}$ post-scratch $(10.5 \mathrm{mU}$ $\mathrm{mL}^{-1} \pm 1.1 \mathrm{mU} \mathrm{mL}^{-1}$ vs. $3.8 \mathrm{mU} \mathrm{mL}^{-1} \pm 0.3 \mathrm{mU} \mathrm{mL}^{-1}$ in WT; $11.5 \mathrm{mU} \mathrm{mL}^{-1} \pm 1.5 \mathrm{mU} \mathrm{mL}^{-1}$ vs. $4.8 \mathrm{mU} \mathrm{mL}^{-1}$ $\pm 0.4 \mathrm{mU} \mathrm{mL}^{-1}$ in PV-KO), $48 \mathrm{~h}$ post-scratch $(11.9 \mathrm{mU}$ $\mathrm{mL}^{-1} \pm 1.0 \mathrm{mU} \mathrm{mL}^{-1}$ vs. $6.7 \mathrm{mU} \mathrm{mL}^{-1} \pm 0.7 \mathrm{mU} \mathrm{mL}^{-1}$ in WT; $10.7 \mathrm{mU} \mathrm{mL}^{-1} \pm 1.3 \mathrm{mU} \mathrm{mL}^{-1}$ vs. $4.0 \mathrm{mU} \mathrm{mL}^{-1}$ $\pm 0.4 \mathrm{mU} \mathrm{mL}^{-1}$ in PV-KO) and $72 \mathrm{~h}$ post-scratch $(15.5$ $\mathrm{mU} \mathrm{mL} L^{-1} \pm 2.0 \mathrm{mU} \mathrm{mL}^{-1}$ vs. $8.9 \mathrm{mU} \mathrm{mL}^{-1} \pm 1.2 \mathrm{mU}$ $\mathrm{mL}^{-1}$ in WT; $17.0 \mathrm{mU} \mathrm{mL}^{-1} \pm 1.9 \mathrm{mU} \mathrm{mL}^{-1}$ vs. $9.0 \mathrm{mU}$ $\mathrm{mL}^{-1} \pm 0.8 \mathrm{mU} \mathrm{mL}^{-1}$ in $\mathrm{PV}-\mathrm{KO}$ ) when compared with unlesioned control (Fig. 4A). After 1 week, LDH activity was similar to the pre-scratch values from both scratched and control slices $\left(2.2 \mathrm{mU} \mathrm{mL}^{-1} \pm 0.9 \mathrm{mU} \mathrm{mL}^{-1}\right.$ in WT; $1.5 \mathrm{mU}$ $\mathrm{mL}^{-1} \pm 0.6 \mathrm{mU} \mathrm{mL} \mathrm{m}^{-1}$ in PV-KO). Next, we compared if LDH activity differed between WT and PV-KO scratched slices after subtracting the background of the control slices' activity. We found no significant difference in none of the time-points of the measurements (Fig. 4B; pre-scratch 1.4 $\mathrm{mU} \mathrm{mL}^{-1} \pm 0.3 \mathrm{mU} \mathrm{mL}^{-1}$ in WT vs. $2.5 \mathrm{mU} \mathrm{mL}^{-1} \pm$ $0.5 \mathrm{mU} \mathrm{mL}^{-1}$ in PV-KO, $P=0.07 ; 1 \mathrm{~h}$ post-scratch 3.9 $\mathrm{mU} \mathrm{mL}^{-1} \pm 0.9 \mathrm{mU} \mathrm{mL}^{-1}$ in WT vs. $3.3 \mathrm{mU} \mathrm{mL}^{-1} \pm$ 
A

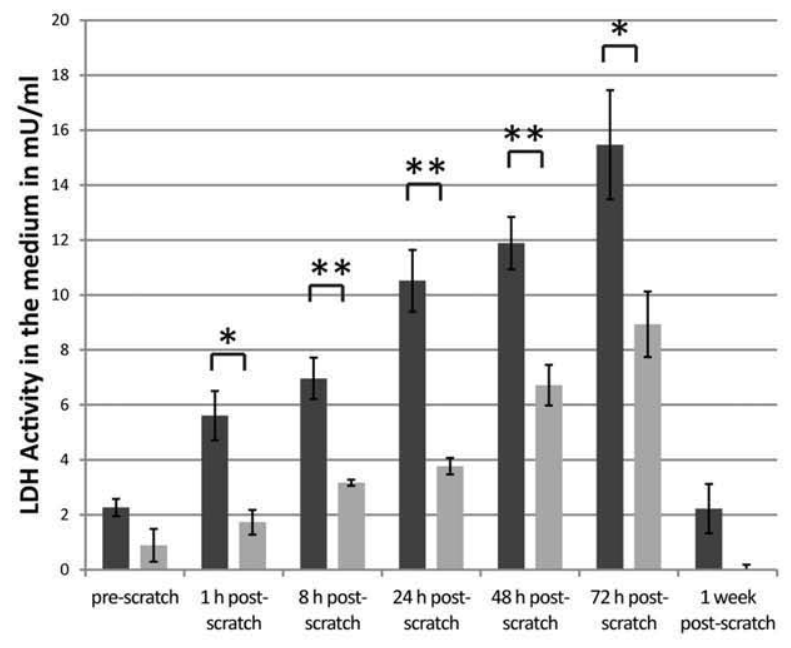

B

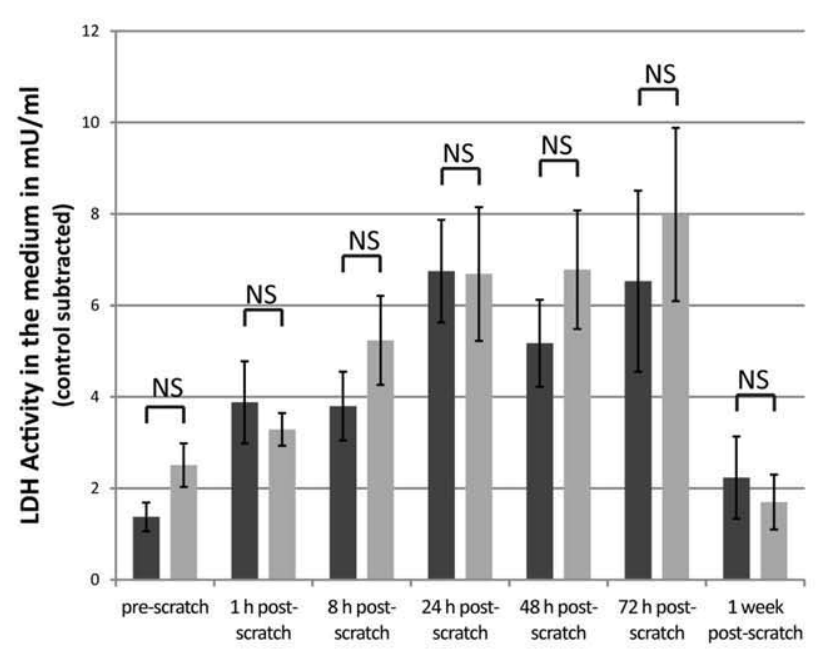

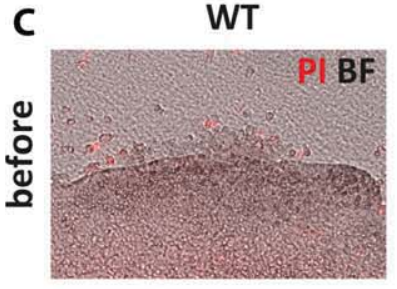

D

PV-KO
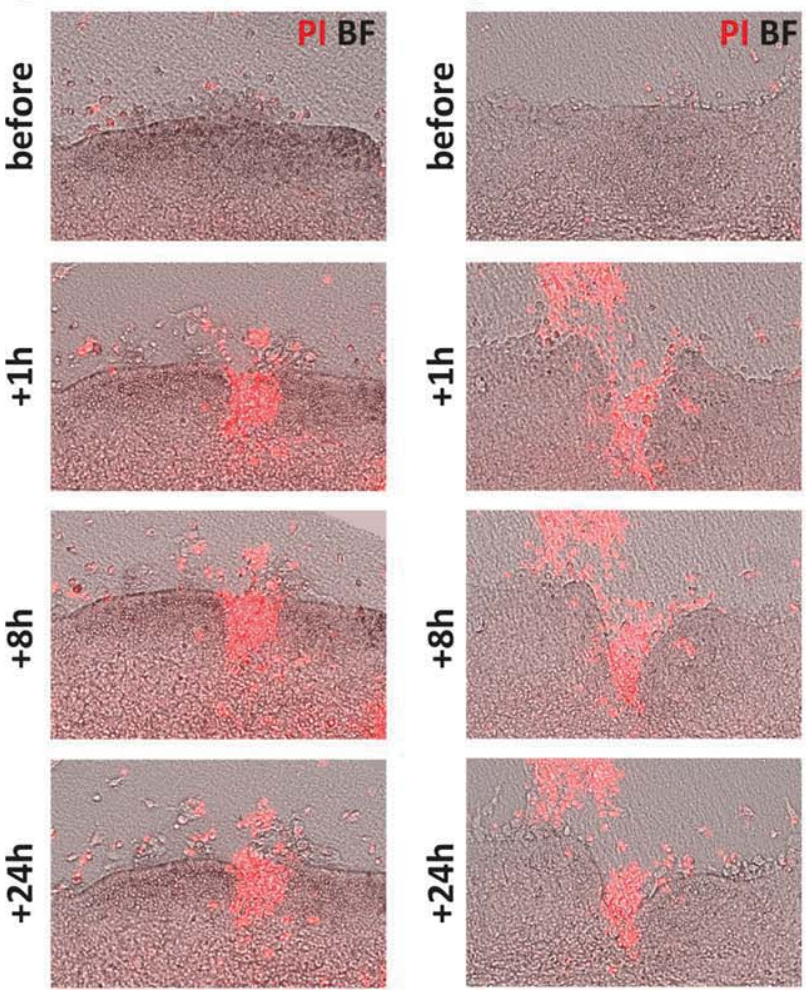
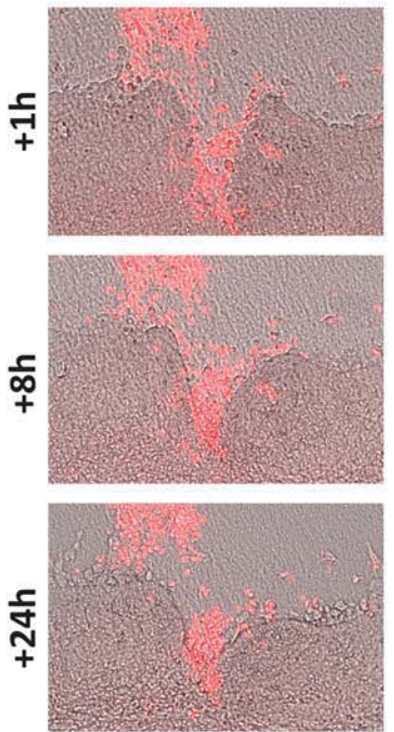

$\mathbf{C}^{\prime}$

WT

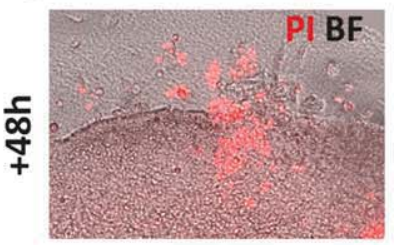

D' PV-KO
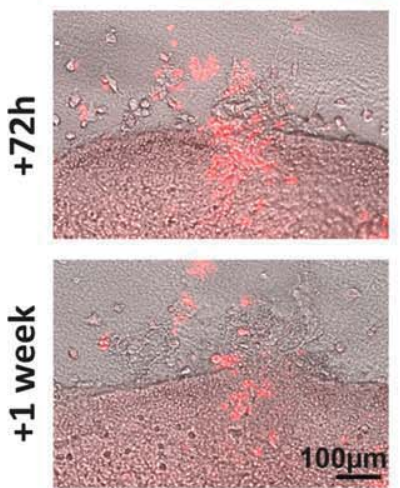
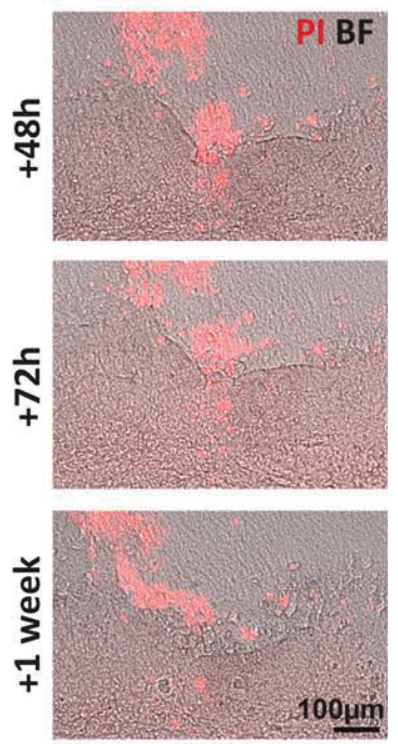

FIGURE 4: Mechanical lesion of ependymal-cell clusters in OHSCs induces cell death in ependymal cells adjacent to the lesion; the degree of cell death measured by LDH release and PI uptake does not differ significantly between PV-KO and their wild-type counterparts. (A) LDH (lactate dehydrogenase) activity (in $\mathrm{mU} \mathrm{mL}^{-1}$ ) in the culture medium of scratched and control ependymal clusters of C57BL/6 OHSCs was detected by a colorimetric assay at seven different time-points ( $1 \mathrm{~h}$ pre-scratch, $1 \mathrm{~h}, 8 \mathrm{~h}, 24 \mathrm{~h}, 48 \mathrm{~h}, 72 \mathrm{~h}$, and 1 week post-scratch). LDH activity was significantly higher in the medium supernatant of scratched slices than in that of control slices at 1 , $8,24,48$, and $72 \mathrm{~h}$ following the lesion. The increase in LDH activity dropped to non-significant in the culture medium 1 week following mechanical lesion. Error bars show SEM. ( ${ }^{*}: P<0.05$, **: $P<0.005$, Student's $t$ test). (B) LDH activity (in $\mathrm{mU} \mathrm{mL}^{-1}$ ) in the culture medium of scratched ependymal clusters of C57BL/6 and PV-KO OHSCs at different time-points following background subtraction (LDH activity of the control slices) show increase in cell death in both WT and PV-KO following scratching as compared with the pre-scratch levels. The level of LDH activity drops to pre-scratch levels at 1 week after scratching. There is no significant difference between LDH activity measured in scratched PV-KO and WT slices in none of the time-points. (C) Time-lapse image sequence of propidium iodide (PI, red) uptake merged with the brightfield images in WT ependymal-cell cluster before and $1 \mathrm{~h}, 8 \mathrm{~h}, 24 \mathrm{~h}, 48 \mathrm{~h}, 72 \mathrm{~h}$, and 1 week following scratching. (D) Time-lapse image sequence of propidium iodide (PI, red) uptake merged with the brightfield images in PV-KO ependymal-cell cluster 1 h pre-scratch and 1 h, 8 h, 24 h, 48 h, 72 h, and 1 week following scratching. 
$0.4 \mathrm{mU} \mathrm{mL}^{-1}$ in PV-KO, $P=0.55 ; 8 \mathrm{~h}$ post-scratch 3.8 $\mathrm{mU} \mathrm{mL} \mathrm{mL}^{-1} \pm 0.8 \mathrm{mU} \mathrm{mL}^{-1}$ in WT vs. $5.2 \mathrm{mU} \mathrm{mL}^{-1} \pm$ $1.0 \mathrm{mU} \mathrm{mL}^{-1}$ in PV-KO, $P=0.27 ; 24 \mathrm{~h}$ post-scratch 6.7 $\mathrm{mU} \mathrm{mL} \mathrm{mL}^{-1} \pm 1.1 \mathrm{mU} \mathrm{mL}^{-1}$ in WT vs. $6.7 \mathrm{mU} \mathrm{mL}^{-1} \pm$ $1.5 \mathrm{mU} \mathrm{mL}^{-1}$ in PV-KO, $P=0.97$; $48 \mathrm{~h}$ post-scratch 5.2 $\mathrm{mU} \mathrm{mL} \mathrm{mL}^{-1} \pm 1.0 \mathrm{mU} \mathrm{mL}^{-1}$ in WT vs. $6.8 \mathrm{mU} \mathrm{mL}^{-1} \pm$ $1.3 \mathrm{mU} \mathrm{mL}^{-1}$ in PV-KO, $P=0.34 ; 72 \mathrm{~h}$ post-scratch 6.5 $\mathrm{mU} \mathrm{mL} \mathrm{m}^{-1} \pm 2.0 \mathrm{mU} \mathrm{mL}^{-1}$ in WT vs. $8.0 \mathrm{mU} \mathrm{mL}^{-1} \pm$ $1.9 \mathrm{mU} \mathrm{mL}^{-1}$ in PV-KO, $P=0.61 ; 1$ week post-scratch 2.2 $\mathrm{mU} \mathrm{mL}^{-1} \pm 0.9 \mathrm{mU} \mathrm{mL}^{-1}$ in WT vs. $1.7 \mathrm{mU} \mathrm{mL}^{-1} \pm$ $0.6 \mathrm{mU} \mathrm{mL}^{-1}$ in PV-KO, $P=0.63$ ). We also confirmed these results by visually observing propidium iodide uptake at the same time-points as above in both WT and PV-KO scratched slices (Fig. 4C,D). By the visualization of PI uptake in several scratched slices, qualitatively we could observe large amount of dead cells in the scratch and in its vicinity, whereas the spared ependyma adjacent to the scratches showed only minimal PI uptake in few single cell nuclei in both WT and PV-KO. A quantitative analysis, e.g. number of dead cells proved to be difficult due to the excessive cell debris - emitting strong patch-like red fluorescence-found in the scratch-wound (Fig. 4C,D), nevertheless, by carefully observing all the scratched WT and PV-KO slices, there appeared to be abundant PI-uptake in the cell nuclei in the cell debris of the scratch wounds, confirming the result of the $\mathrm{LDH}$ activity quantitation.

\section{Up-regulation of Parvalbumin in the Ependymal Cells of OHSCs can be Inhibited by Blocking NF-KB and Decreased by Antioxidant Treatment}

The observation that the de novo expression of PV in ependymal cells follows injury raises the question as to which factors are involved in the induction process. In an experimental model of acute inflammation induced by a peripheral injection of lipopolysaccharides, the transcriptome of the choroid plexus-a double-layered fold of the pia mater that is covered with a sheet of ependymal cells - manifested an early increase in the expression of chemo- and cytokines (IL-6, IL-1 $\beta$, TNF- $\alpha$, etc.), as well as in that of the inflammatory regulator transcription factor NFKB (Marques et al., 2009). Because ependymal cells express cytokine receptors on their basolateral membrane (Marques et al., 2011), we wondered whether the expression of PV could be induced by inflammatory cytokines or by their mediators.

To identify the nature of the soluble cytokines that were present in OHSCs, aliquots of the supernatant medium were withdrawn for analysis at defined intervals after the preparation of the OHSCs from C57BL/6 mice. A cytokine-antibody array was utilized for this purpose. The analysis revealed the culture medium to contain a broad spectrum of cytokines. About $24 \mathrm{~h}$ after the onset of culturing, IL- 6 was expressed at the highest level, with a remarkable presence of VCAM-1, G-CSF, CXL16, and sTNFRI (Fig. 5A). Hence, during preparation and culturing of OHSCs, intrinsic cells of the slices do indeed secrete inflammatory cytokines, any of which could potentially play a role in the induction of PV-expression.

NF-KB-signaling is involved in cellular responses to strong stimuli, such as stress and inflammation. By regulating the expression of cytokines and growth factors, NF-KB-signaling controls the survival of cells and the immune response (Ghosh et al., 1998). We observed that blockage of NF-KB-signaling led to an almost complete inhibition of PV-expression in the ependymal cells of OHSCs by DIV5 (Fig. 5B). When exposing the dissectionand culturing medium of OHSCs of PV-Cre/loxP-DsRed-loxPEGFP mice to inhibitors of the NF-KB-signaling, PV-driven EGFP was present only in a few scattered cells in the region of the ependymal-cell cluster, while most ependymal cells expressed DsRed. In contrast, the control, untreated ependymal-cell clusters displayed numerous cells that expressed PV-driven EGFP (Fig. 5B). This finding suggests that the de novo PV-synthesis in ependymal cells is dependent on NF-KB-signaling. Inflammation via NF-KB-signaling might result in the upregulation of the Pvalb gene also in other epithelial systems, based on gene-expression data collected from the GEO Profiles DataBase (NCBI). Pvalb was upregulated in skin cells in an inflammatory skin phenotype mouse model with keratinocyte-specific IKB kinase beta (IKKbeta) overexpression (GEO Accession: GDS3766); likewise, in the prostate epithelium in a mouse model for inflammatory signaling based on expression of a constitutively active version of IкB kinase 2 (IKK2ca) (GEO Accession: GDS4119).

To ascertain whether the injury-induced expression of $\mathrm{PV}$ in ependymal cells is mediated by an elevated level of oxidative stress, OHSCs were exposed to either $N$-acetyl-cysteine (NAC) or buthionine sulfoximine (BSO). NAC suppresses the production of reactive oxygen species, whereas $\mathrm{BSO}$ inhibits the activity of gamma-glutamylcysteine synthetase, whereby the level of gluthatione is reduced and the degree of oxidative stress thereby heightened. PV-immunoreactivity was observed in ependymal cells by DIV7 in each case (Fig. 5C). Next, we quantified the mean fluorescent intensity of the PVimmunostaining to estimate the amount of this $\mathrm{CaBP}$ present in the ependymal-cell clusters. The quantification revealed the fluorescent intensity of the PV-immunostaining to be significantly lower after NAC-treatment than that of the control, untreated slices (Fig. 5D). This effect was dose-dependent: the fluorescent intensity of the PV-immunostaining was lower after exposing the slices to $500 \mu \mathrm{M}$ NAC than when exposed to $100 \mu \mathrm{M}$ NAC. In contrast, exposure to BSO did not result in a significant difference in the fluorescent intensity of the PV-immunostaining as compared with the control slices (Fig. 5D). The findings indicate that exposure of the culture medium to antioxidants decreases the injury-evoked induction of PV-synthesis, whilst exposure to stronger oxidative stress has no influence on it. 

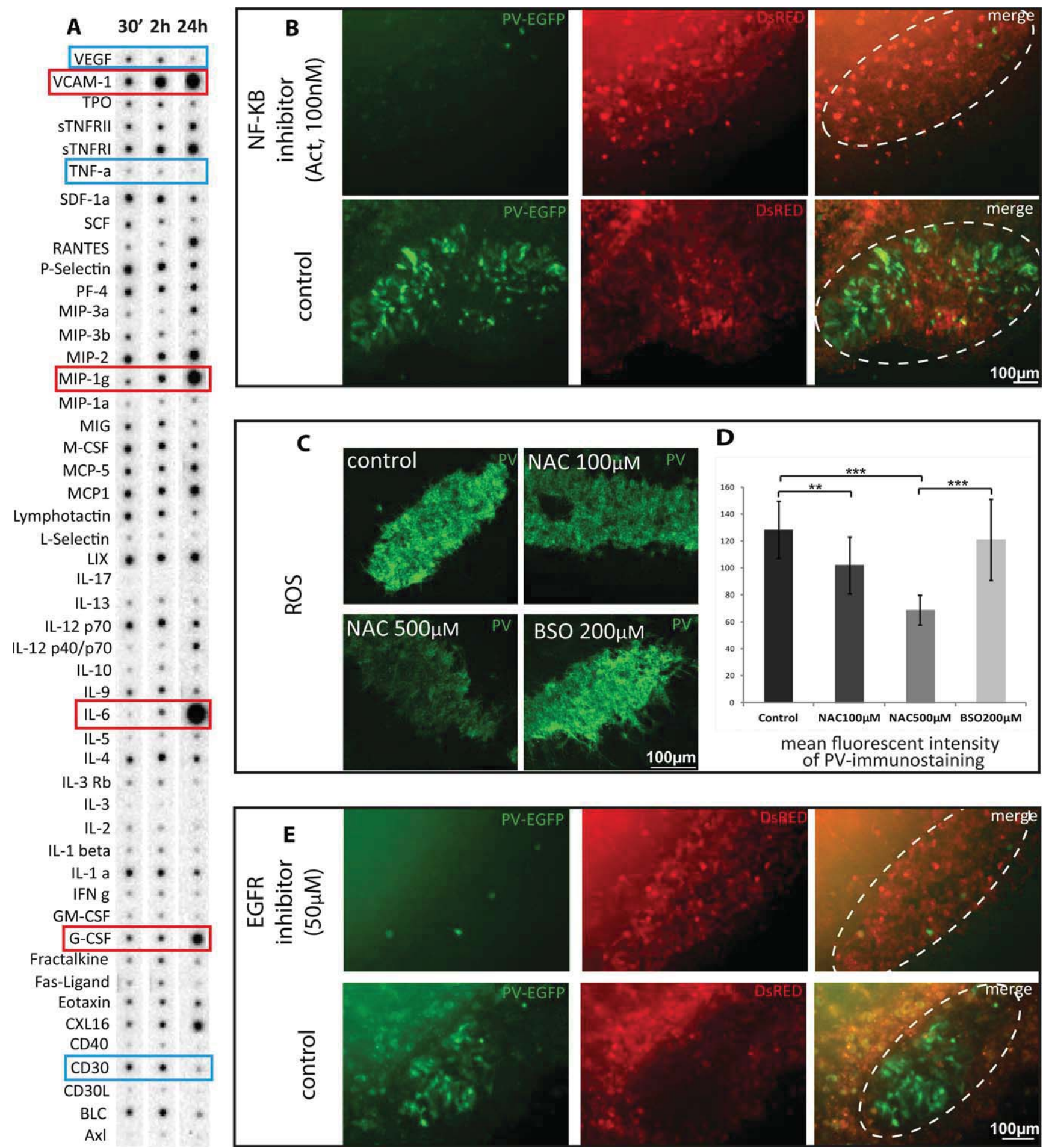

FIGURE 5: Regulation of PV-expression in ependymal cells by inflammatory regulator NF-KB, oxidative stress and EGFR signaling. (A) A cytokine antibody array was performed to reveal cytokines present in the medium supernatant $30 \mathrm{~min}, 2 \mathrm{~h}$, and $24 \mathrm{~h}$ after the preparation of OHSCs of C57BL/6 mice. Some inflammatory cytokines exhibited a massive increase after 24 h, such as IL-6, GCSF, VCAM-1, MIP-1g (marked by red rectangles). Other cytokines decreased in concentration, e.g. VEGF, TNF-alpha, CD30 (marked by blue rectangles). (B) Live fluorescent images of ependymal-cell clusters (marked by dashed ellipses) in OHSC of a PV-Cre/EGFP mouse at DIV5 treated with the NF-KB inhibitor Act (100nM), as compared with untreated controls show that NF-KB inhibition results in decreased PVdriven EGFP expression in almost all ependymal cells. Control ependymal cells, in contrast, show intense PV-promoter driven EGFP expression. Cells not expressing PV are DsRed-positive. (C) Confocal laser micrographs of ependymal-cell clusters in OHSCs of a C57BL/ 6 mouse fixed on DIV7 treated with modulators of oxidative stress and immunostained for PV. Slices were treated with the antioxidant $\mathrm{N}$-acetyl-cysteine (NAC) to reduce oxidative stress or with the GSH-synthesis inhibitor buthionine sulfoximine (BSO) to enhance oxidative stress. (ROS: reactive oxygen species). (D) The mean fluorescent intensity of the PV-staining shows lower intensity values in ependymalcell clusters treated with NAC than in untreated control or following BSO treatment. E.) Live fluorescent images of ependymal-cell clusters (marked by dashed ellipses) in OHSC of a PV-Cre/EGFP mouse at DIV5 treated with EGFR-inhibitor (50 $\mu \mathrm{M})$, as compared with untreated controls show that in treated slices, PV-expression is restricted to some single cells, whereas the untreated control ependymal-cell cluster expresses abundant PV-driven EGFP. Error bars show the standard deviation. (**P<0.005; $\left.{ }^{\star \star \star}: P<0.0005\right)$. 
Our experiments reveal the de novo expression of PV to be related to the injury-induced secretion of inflammatory mediators. The level of PV-production in ependymal cells is inversely proportional to the degree of oxidative stress. Given that PV-positive interneurons are highly susceptible to oxidative-stress-induced damage (Cabungcal et al., 2006), this is a surprising finding. After treatment with BSO, the number of PV-positive interneurons in OHSCs did indeed drop significantly, whereas after NAC-treatment a slight increase in this parameter was observed (data not shown). These findings indicate that the expression of PV is regulated differently in reactive ependymal cells and in PV-positive interneurons.

\section{Up-regulation of Parvalbumin is Modulated by EGFR-signaling: A Possible Role in Injury-Induced Remodeling}

Signaling via the epidermal growth factor receptor (EGFR) induces radial-glial phenotype in the ependymal cells (Gregg and Weiss, 2003). It also plays a role in injury-induced tissue remodeling: wounding of epithelia triggers the activation of the EGFR, which is implicated in the induction of cell motility (Block and Klarlund, 2008). Acting on EGFR, TGF- $\alpha$ was shown to induce a massive increase in the rate of proliferation of SVZ- and VZcells after injury (Fallon et al. 2000; Gleason et al., 2008). Following spinal cord injury, EGFR is upregulated by glial progenitors and an intrinsic EGFR activation is necessary for normal glial scar formation (White et al., 2011). Furthermore, the administration of EGF to mice that have been subjected to cerebral ischemia leads to a replenishment of PV-positive neurons in the injured striatum (Teramoto et al., 2003).

We investigated the possibility that the de novo expression of PV in ependymal cells might depend upon EGFRsignaling by exposing OHSCs of PV-Cre/loxP-DsRed-loxPEGFP mice to the EGFR inhibitor cyclopropanecarboxylic acid-dianilinopyrimidine $(50 \mu \mathrm{M})$ (Fig. 5F). The result was similar to that observed after the inhibition of NF-KB-signaling: PV-driven EGFP was absent from most ependymal cells by DIV5, when compared with the untreated control. Indeed, ependymal cells of the OHSCs exposed to EGFR-inhibitor displayed DsRed, while most untreated ependymal cells expressed EGFP (Fig. 5F). This suggests that PV-synthesis was inactive in ependymal cells when EGFR-signaling was counteracted. In the light of this finding, we hypothesize that injury and the ensuing process of remodeling might activate EGFR signaling, which in turn induces-directly or indirectly-the expression of PV in ependymal cells.

\section{The Lack of Parvalbumin in PV-Knock-Out Mice Influences the Organization of Ependymal Cells in OHSC}

Adult wild-type and PV-KO mice have a similar, normal ependymal phenotype both at the lateral wall of the anterior lateral ventricle and at the lining of the hippocampus (Fig. 6A,B), suggesting that PV-deficiency does not influence the normal development and the function of the ependymal cells under physiological conditions.

Next, we investigated the degree to which the absence of PV influences ependymal cell phenotype following an injury. For this purpose, we used OHSCs of C57BL/6 and PV-KO/EGFP mice.

To investigate the consequences of a lack of PV in ependymal cells, the OHSCs of PV-KO/EGFP mice were maintained for several weeks, followed by fixation at different time-points after the onset of culturing, and their morphological features were compared with those of their wild-type (WT) counterparts. After 1 week of culturing, the EGFPexpressing cells that were derived from the PV-KO/EGFP mice were less tightly packed than were their PV-expressing wild-type counterparts (Fig. 7A). After 2 weeks, the EGFPimmunostained ependymal cells were sparser, less well organized and more irregular in shape than were their PVexpressing counterparts. After 3 and 4 weeks, respectively, the difference between the ependymal clusters of PV-KO and wild-type mice became progressively more pronounced: the PV-KO/EGFP-positive cells were sparse and often made contact with each other via cytoplasmic processes, not via their cell bodies (Fig. 7A). Transmission electron microscopy revealed additional morphological changes (Fig. 7B). At DIV7, the contacting cell membranes of adjacent ependymal cells in wild-type OHSCs were characterized by widespread interdigitations, which were maintained until DIV31. In the OHSCs of PV-KO/EGFP mice, the intercellular connections were looser at DIV7, yawning gaps existed between neighboring cells and the interdigitations were less prominent. At DIV31, interdigitations were seldom observed and the intercellular contacts were characterized by smooth surface contours. Our findings indicate that in tissue cultures, the absence of parvalbumin has a profound influence on the morphology of ependymal cells and on their organization, revealed by the loosening of the intercellular connections. This could be the consequence of an impaired adaptation to the altered physiological conditions found ex vivo in the absence of parvalbumin.

\section{A Comparative Gene-microarray Analysis of PV-KO Ependymal-cell Aggregates Reveals Major Differences at the Gene Expression Level, Including Genes Implicated in Cytoskeletal Remodeling and in the Response to Hypoxia}

To improve our understanding of the molecular mechanisms that contribute to the fine-tuning of PV-expression, and to identify the genes that are differentially regulated in the cascade of events following injury, ependymal cells that were 

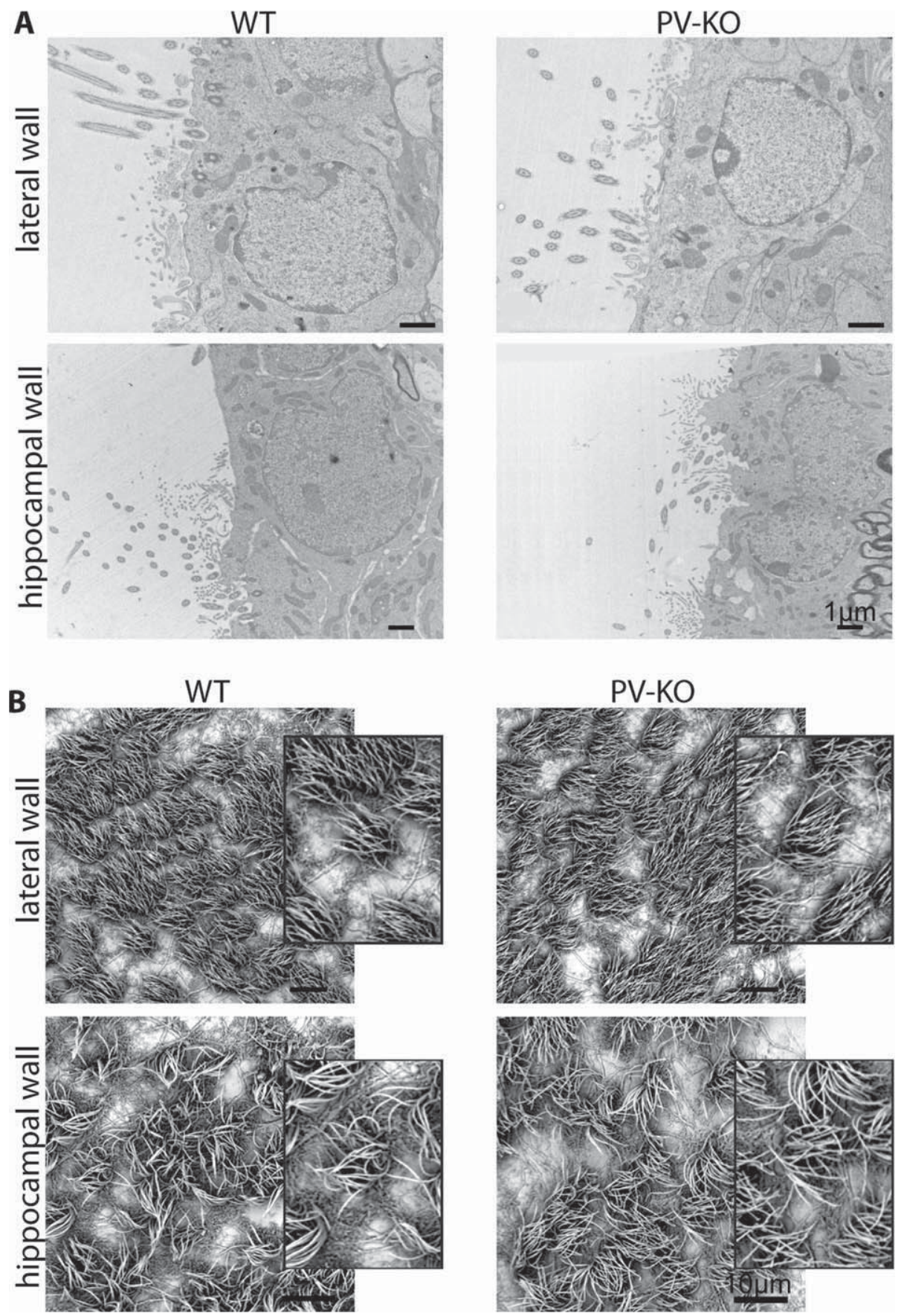

FIGURE 6: Ependymal cells of the lateral ventricle in the adult murine brain retain a healthy ultrastructure in both C57BL/6 and PV-KO mice. (A and B) As shown by transmission (A) and scanning (B) electron micrographs, wild-type and PV-KO adult mice possess a normalappearing ependymal cover at the lateral wall of the anterior lateral ventricle (level of the caudatoputamen) and at the medial wall at the level of the hippocampus.

isolated from the DIV21-OHSCs of wild-type and PV-KO mice were subjected to a comparative whole-transcriptome analysis (Fig. 7C,D). Using a fold-change cut-off level of $\geq 2$ at an adjusted $P$ value of $0.05 \%, 576$ genes were downregulated and 346 up-regulated in the ependymal cells of PV$\mathrm{KO}$ mice. That so many genes were differentially expressed in the ependymal cells of the two strains of mice suggests that the absence of PV has a profound influence on their basic physiological activity. To elucidate the pathways and processes that might be implicated in the response of PV-expressing ependymal cells to injury, we concluded a GeneGo and Gene Set Enrichment Analysis (GSEA) on the genes that were differentially expressed in the ependymal cells of the two strains of mice at a fold-change cut-off level of $\geq 1.5$ and an adjusted 
A
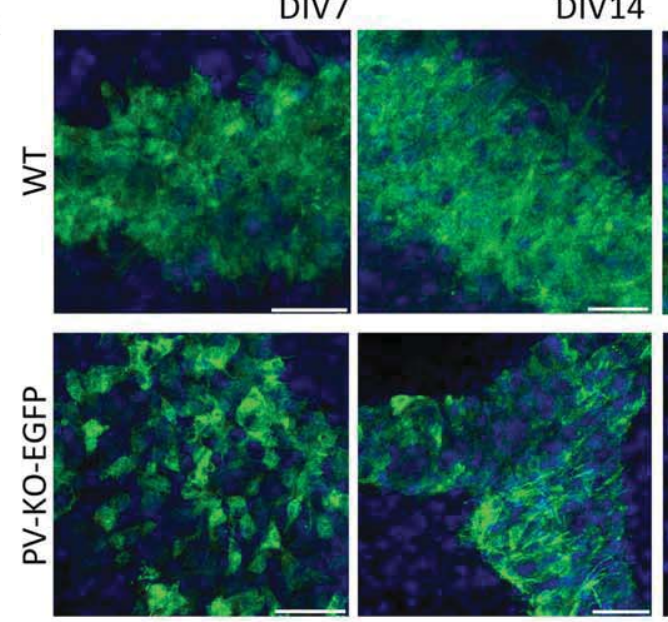

B
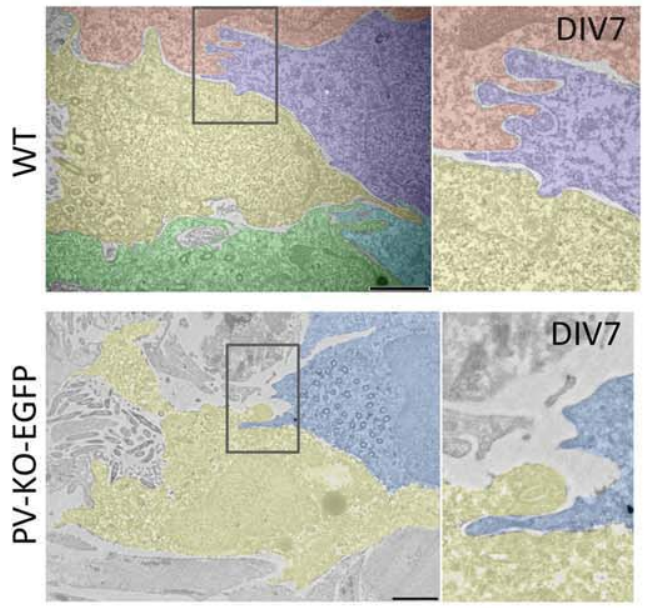

DIV21
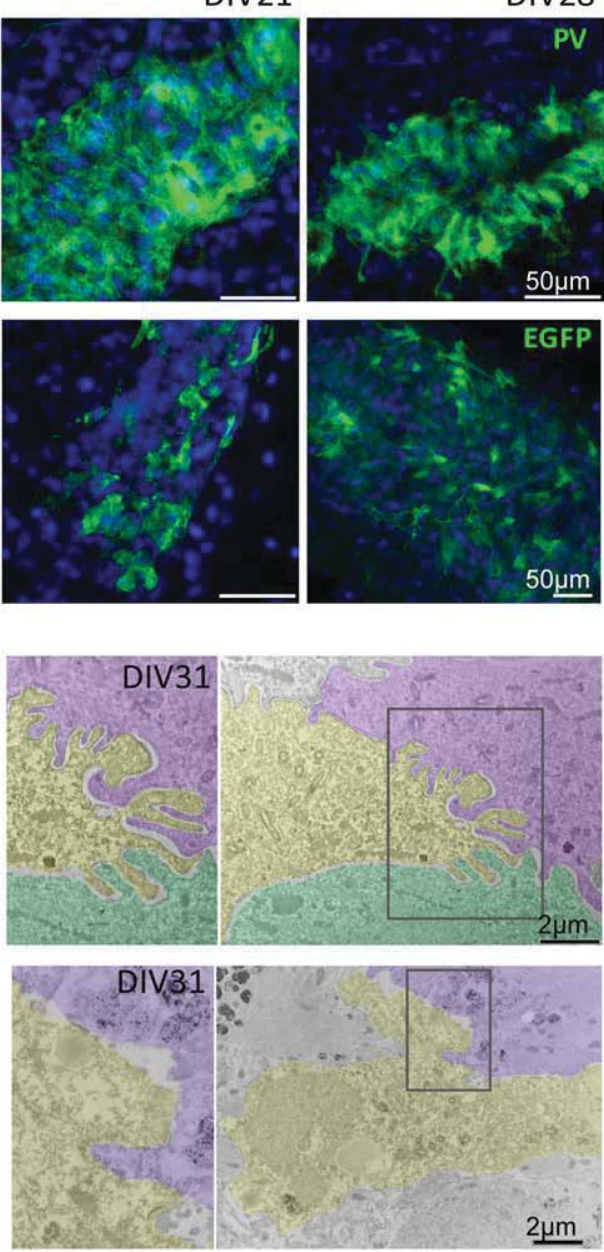

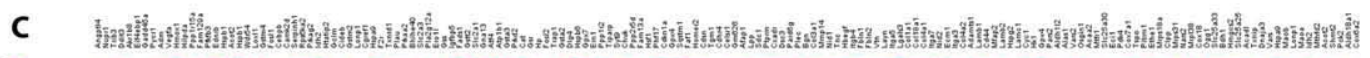
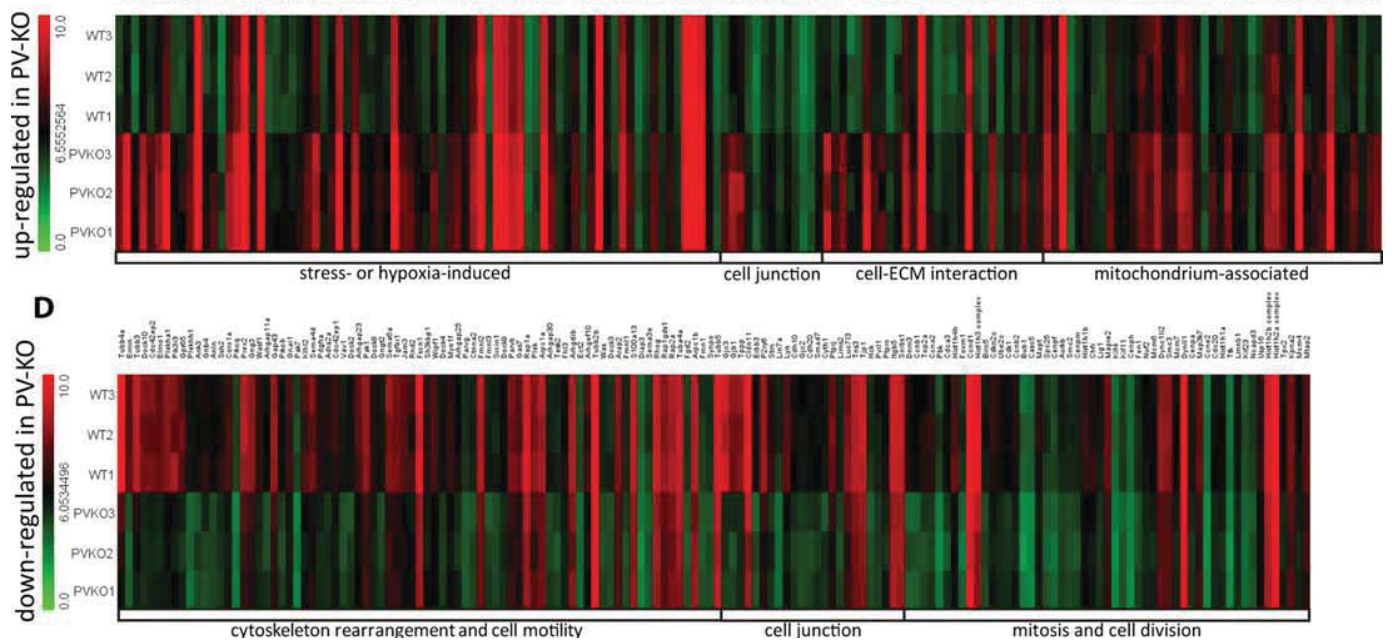

FIGURE 7: Ultrastructural changes in aged ependymal cell-clusters of PV-KO/EGFP OHSCs reveal loosening of the ependymal-cell organization and a simultaneous disappearance of intercellular interdigitations in the absence of PV. (A) Confocal z-stack projections comparing PVimmunohistochemistry in wild-type ependymal-cell clusters to EGFP-immunohistochemistry in PV-KO/EGFP ependymal-cell clusters in OHSCs from DIV7 until DIV28. In wild-type mice, PV-immunohistochemistry reveals compact, dense organization of ependymal cells from DIV7 until DIV28 in the ependymal-cell clusters. In PV-KO/EGFP ependymal-cell clusters, cells are less densely packed at DIV7, and lose contact over time. (B) Transmission electron micrographs of wild-type and PV-KO/EGFP ependymal cells of OHSCs at DIV7 and at DIV31, labeled with PV-, resp. EGFPantibodies, and revealed by DAB confirm these findings. Single DAB-stained cells were pseudocolored to better distinguish between cell borders. Wild-type ependymal cells appear packed together with neighboring cells, and display intensive interdigitations of the lateral cell membranes at the sites of intercellular junctions at DIV7, which can be observed at DIV31 as well. In comparison, DIV7 PV-KO/EGFP ependymal cells display wider gaps in between neighboring cells and their intercellular surface appears smoother. At DIV31, PV-KO/EGFP ependymal cells are scattered and have lost connections and interdigitations. (C and D) A gene microarray study was performed to understand the differences at the gene expression level between wild-type and PV-KO ependymal-cell aggregates of DIV21 OHSCs. (C) Out of the selected up-regulated genes, 77 are involved in hypoxia-induced stress responses and cell cycle arrest, 13 in cell adhesion and cell junctions, 28 in extracellular matrix remodeling and cell-matrix interactions, and 43 genes are mitochondria-associated. (D) Among the selected down-regulated genes in PV-KO extracts, 79 are involved in the regulation of cytoskeleton remodeling, 24 in cell adhesion and cell junctions, 53 in cell division, and different phases of mitosis and cytokinesis. 
p value of $0.05 \%$. GeneGO analysis revealed the differential expression of numerous pathways and biological processes. The pathways that were notably impacted included those that are involved in the remodeling of the extracellular matrix (ECM), in the remodeling of the cytoskeleton, in the regulation of Rho/Rac/Cdc42 pathways involved in cell motility, in cell adhesion and in cell-matrix interactions. In the ependymal cells of the PV-KO mice, down-regulated genes included those that are involved in the rearrangement of the cytoskeleton, in ephrin-signaling, in microtubule- and spindleassembly, in the initiation of mitosis and cell division, and in the general immune response (e.g., phagocytosis- and chemotaxis-related genes). Up-regulated genes included those that are involved in the responses to hypoxia and oxidative stress, the remodeling of the ECM, in cell-matrix interactions and in glutathione metabolism. We postulated that the crucial processes underlying the differences between the injured ependymal cells of wild-type and PV-KO mice impacted cytoskeletal remodeling. This process is necessary to enhance the motility of the cells, which permits their re-adaptation to changes in the microenvironment and to injury-induced stress. In the ependymal cells of the PV-KO mice, a subset of genes (such as Ank3, Rhob, Rhog, Pak1, Vav1, Wasf1, Arpc1a, Arpc1b, Cdc42ep1, Rap1a) that is involved in the regulation of cytoskeletal rearrangement was indeed down-regulated (Table 2), thereby implying impairment in the regulation of cell motility and cell shape. In contrast, 34 genes that are involved in the responses of cells to hypoxia and oxidative stress (such as Hmox1, Gadd45a, Lox, Nupr1, Gss, Gsr, Gsta3, Gstm2, Cebpb, Fosl1) were up-regulated in PV-KO (Table 2). However, 7 genes that are likewise involved in the response to hypoxia were down-regulated, thereby indicating that alternative mechanisms may be operative at the absence of PV. A number of other genes were also differentially expressed in the ependymal cells of the two strains of mice. These included those that are involved in cell adhesion and in the regulation and assembly of cell junctions. A set of genes encoding mitochondrial proteins and enzymes was upregulated in the ependymal cells of PV-KO mice. This finding accords with existing data that point to an inverse correlation between the PV-content and mitochondrial volume of different cell types (Chen et al., 2006).

Using GSEA analysis at a cut-off level of false discovery rate (FDR) of $<0.05 \%$ and family wise error rate (FWER) of $<0.05 \%$, seven gene sets were positively enriched in the ependymal cells of the PV-KO mice; one was negatively enriched. The positively enriched gene sets were those that are involved in the response to hypoxia and in the response of cancer cells to treatment with receptor tyrosine kinase (RTK)-inhibitors, Ras-inhibitors and arsenic trioxide. These findings indicate that in the ependymal cells of the PV-KO mice, the levels of general stress, hypoxia and growth inhibition were increased. The single gene set that was negatively enriched in the ependymal cells of the PV-KO mice is implicated in the development of oligodendrocytes. However, in the present study, we did not investigate whether the development of oligodendrocytes and their myelinating capacity are related to the injuryinduced de novo expression of PV in ependymal cells.

\section{Parvalbumin is Up-regulated in Ependymal Cells After In vivo Injury of the Lateral Ventricular Wall}

To ascertain whether the injury-induced up-regulation of PV in the ependymal cells occurs also in vivo, the lateral ventricle wall of adult wild-type and PV-KO/EGFP mice was lesioned with a stab-wound (Fig. 8A,B). Seven days after lesioning the animals were transcardially perfused and the brains were processed for immunohistochemistry. Seven days post-injury, the ependymal layer on the injured side manifested PVimmunoreactivity (Fig. 8C,E), whereas in that of the shamoperated mice (not shown) and in that on the uninjured side no immunoreactivity for PV was observed in the lateral ventricle wall (Fig. 8D,E'). Six weeks following lesioning, PVimmunoreactivity was still present in the ependymal layer adjacent to the stab lesion (Fig. 8F), although at a more moderate level than at 1-week-post-injury; whereas it was virtually absent on the unlesioned side (Fig. 8F'). PV-immunostaining of the ependymal layer occurred along the entire length of the lesion, as was revealed by the inspection of 1-week-postinjury consecutive coronal sections (Fig. 8G-G"'). In PV-KO/ EGFP mice (in which the parvalbumin-promoter is active, although no PV is produced), the ependymal layer manifested intense immunoreactivity for EGFP 1-week-post-injury (Fig. $8 \mathrm{H}-\mathrm{H} ",, 8 \mathrm{~J})$. These findings suggest that the lesioning of the lateral ventricle wall activates the Pvalb-promoter in the ependymal cells. However, while in wild-type mice PVimmunoreactive cells occurred both in the ependymal layer and in the vicinity of the lesion (Fig. 8I), in the PV-KO/ EGFP mice EGFP-immunoreactivity was confined to cells of the ependymal layer (Fig. 8J). Lesioned wild-type mice manifested wound-closure and scar formation around the lesion, while these were virtually absent from PV-KO/EGFP mice. We also performed GFAP immunostaining to mark reactive astrocytes around the injury and the VZ (Fig. 8I,J). We found that numerous astrocytes were present around the lesion in both PV-KO-EGFP and wild-type mice; however, a scar tissue with massive GFAP staining was present only in the wild-type (Fig. 8I). In addition, in the cells of the scar tissue that reunited the wound rims, GFAP and PV were co-localized in the same cells (inset, Fig 8I), suggesting that scar forming astrocytes might also express the CaBP. We have observed PV-immunopositive cells in the stab-wound region also 6weeks-post-injury (inset, Fig. 8F) just above the ependymal 
TABLE 2: Genes Differentially Expressed in WT and PV-KO Ependymal Cells in DIV21-OHSCs

$\begin{array}{llll}\text { ID } & \begin{array}{l}\text { Fold } \\ \text { change }\end{array} & \text { adj.P.Val } & \begin{array}{l}\text { Gene } \\ \text { symbol }\end{array}\end{array}$ Gene description

\section{Cytoskeletal rearrangement, regulation of cell shape and cell motility}

\begin{tabular}{|c|c|c|c|c|}
\hline 10527430 & -1.83 & 0.0048919 & Arpcla & actin related protein $2 / 3$ complex, subunit $1 \mathrm{~A}$ \\
\hline 10527441 & -1.57 & 0.028817 & Arpclb & actin related protein $2 / 3$ complex, subunit $1 \mathrm{~B}$ \\
\hline 10363786 & -3.64 & 0.0006517 & Ank3 & ankyrin 3, epithelial \\
\hline 10530100 & -1.69 & 0.004705 & Arap2 & $\begin{array}{l}\text { ArfGAP with RhoGAP domain, ankyrin repeat and } \mathrm{PH} \\
\text { domain } 2\end{array}$ \\
\hline 10413771 & -1.77 & 0.0278853 & Capn7 & calpain 7 \\
\hline 10545538 & -2.02 & 0.0025788 & Ctnna2 & catenin (cadherin associated protein), alpha 2 \\
\hline 10425116 & -2.41 & 0.0023557 & Cdc42ep1 & CDC42 effector protein (Rho GTPase binding) 1 \\
\hline 10465278 & -5.83 & 0.0001519 & Cdc42ep2 & CDC42 effector protein (Rho GTPase binding) 2 \\
\hline 10568024 & -2.89 & 0.0003017 & Corola & coronin, actin binding protein $1 \mathrm{~A}$ \\
\hline 10356020 & -6.95 & $6.51 \mathrm{E}-05$ & Dock10 & dedicator of cytokinesis 10 \\
\hline 10385118 & -2.40 & 0.008793 & Dock2 & dedicator of cyto-kinesis 2 \\
\hline 10596583 & -1.69 & 0.0309273 & Dock3 & dedicator of cyto-kinesis 3 \\
\hline 10395466 & -2.13 & 0.000965 & Dock4 & dedicator of cytokinesis 4 \\
\hline 10462140 & -2.31 & 0.0004627 & Dock8 & dedicator of cytokinesis 8 \\
\hline 10422436 & -1.97 & 0.0022849 & Dock9 & dedicator of cytokinesis 9 \\
\hline 10421877 & -1.66 & 0.0311587 & Diap3 & diaphanous homolog 3 (Drosophila) \\
\hline 10497520 & -1.76 & 0.0025788 & Ect2 & ect 2 oncogene \\
\hline 10403842 & -5.05 & 0.0001519 & Elmo1 & $\begin{array}{l}\text { engulfment and cell motility } 1 \text {, ced- } 12 \text { homolog (C. } \\
\text { elegans) }\end{array}$ \\
\hline 10482795 & -12.02 & $5.84 \mathrm{E}-05$ & Ermn & ermin, ERM-like protein \\
\hline 10527158 & -2.20 & 0.00327 & Fscn 1 & $\begin{array}{l}\text { fascin homolog } 1 \text {, actin bundling protein (Strongylocentro- } \\
\text { tus purpuratus) }\end{array}$ \\
\hline 10474619 & -1.55 & 0.033766 & Fmn1 & formin 1 \\
\hline 10381708 & -1.68 & 0.0131622 & Fmnl1 & formin-like 1 \\
\hline 10472097 & -2.01 & 0.0009141 & Fmnl2 & formin-like 2 \\
\hline 10432439 & -2.00 & 0.0239411 & Fmnl3 & formin-like 3 \\
\hline 10397645 & -4.66 & 0.0012817 & Gpr65 & G-protein coupled receptor 65 \\
\hline 10377215 & -1.88 & 0.011931 & Gas7 & growth arrest specific 7 \\
\hline 10439514 & -2.81 & 0.0010624 & Gap43 & growth associated protein 43 \\
\hline 10385248 & -2.37 & 0.0041239 & $\mathrm{Hmmr}$ & hyaluronan mediated motility receptor (RHAMM) \\
\hline 10443980 & -2.06 & 0.0030496 & Myolf & myosin IF \\
\hline 10555118 & -2.35 & 0.0005103 & Pak1 & p21 protein $(\mathrm{Cdc} 42 / \mathrm{Rac})$-activated kinase 1 \\
\hline 10488033 & -2.63 & 0.0021231 & Pak7 & p21 protein $(\mathrm{Cdc} 42 / \mathrm{Rac})$-activated kinase 7 \\
\hline 10425852 & -1.92 & 0.0085373 & Parvb & parvin, beta \\
\hline 10425866 & -2.03 & 0.0015526 & Parvg & parvin, gamma \\
\hline 10507273 & -5.02 & 0.0025367 & Pik3r3 & $\begin{array}{l}\text { phosphatidylinositol } 3 \text { kinase, regulatory subunit, polypep- } \\
\text { tide } 3(\mathrm{p} 55)\end{array}$ \\
\hline
\end{tabular}


TABLE 2: Continued

\begin{tabular}{|c|c|c|c|c|}
\hline ID & $\begin{array}{l}\text { Fold } \\
\text { change }\end{array}$ & adj.P.Val & $\begin{array}{l}\text { Gene } \\
\text { symbol }\end{array}$ & Gene description \\
\hline 10344837 & -2.89 & 0.0020804 & Prex2 & $\begin{array}{l}\text { phosphatidylinositol-3,4,5-trisphosphate-dependent Rac } \\
\text { exchange factor } 2\end{array}$ \\
\hline 10522503 & -2.56 & 0.001122 & Pdgfra & platelet derived growth factor receptor, alpha polypeptide \\
\hline 10384458 & -1.85 & 0.0201384 & Plek & pleckstrin \\
\hline 10558134 & -5.05 & $6.82 \mathrm{E}-05$ & Plekha1 & $\begin{array}{l}\text { pleckstrin homology domain containing, family A (phos- } \\
\text { phoinositide binding specific) member } 1\end{array}$ \\
\hline 10396800 & -4.60 & 0.0001686 & Plekhh1 & $\begin{array}{l}\text { pleckstrin homology domain containing, family } \mathrm{H} \text { (with } \\
\text { MyTH4 domain) member } 1\end{array}$ \\
\hline 10557177 & -2.76 & 0.0015186 & Prkcb & protein kinase $C$, beta \\
\hline 10469255 & -2.89 & 0.0002663 & Prkcq & protein kinase $C$, theta \\
\hline 10502419 & -1.62 & 0.00912 & Rap1gds1 & RAP1, GTP-GDP dissociation stimulator 1 \\
\hline 10399360 & -1.83 & 0.009593 & Rhob & ras homolog gene family, member B \\
\hline 10566132 & -1.63 & 0.007394 & Rhog & ras homolog gene family, member $G$ \\
\hline 10417065 & -1.62 & 0.0109287 & Rap2a & RAS related protein $2 \mathrm{a}$ \\
\hline 10563641 & -1.85 & 0.0093145 & Rap1a & RAS-related protein-1a \\
\hline 10381416 & -2.24 & 0.0128636 & Rnd2 & Rho family GTPase 2 \\
\hline 10546010 & -2.04 & 0.0167092 & Arhgap25 & Rho GTPase activating protein 25 \\
\hline 10351603 & -1.82 & 0.0172861 & Arhgap30 & Rho GTPase activating protein 30 \\
\hline 10548892 & -1.76 & 0.0253338 & Arhgdib & Rho, GDP dissociation inhibitor (GDI) beta \\
\hline 10493789 & -1.67 & 0.0023357 & S100a13 & S100 calcium binding protein A13 \\
\hline 10519747 & -1.64 & 0.0285887 & Sema3e & $\begin{array}{l}\text { sema domain, immunoglobulin domain (Ig), short basic } \\
\text { domain, secreted, (semaphorin) } 3 \mathrm{E}\end{array}$ \\
\hline 10409240 & -2.57 & 0.0016994 & Sema4d & $\begin{array}{l}\text { sema domain, immunoglobulin domain (Ig), transmem- } \\
\text { brane domain (TM) and short cytoplasmic domain, (sema- } \\
\text { phorin) } 4 \mathrm{D}\end{array}$ \\
\hline 10458843 & -2.29 & 0.0032633 & Sema6a & $\begin{array}{l}\text { sema domain, transmembrane domain (TM), and cytoplas- } \\
\text { mic domain, (semaphorin) 6A }\end{array}$ \\
\hline 10602840 & -2.17 & 0.0063362 & Sh3kbp1 & SH3-domain kinase binding protein 1 \\
\hline 10378833 & -3.07 & 0.0005775 & Ssh2 & slingshot homolog 2 (Drosophila) \\
\hline 10390430 & -2.00 & 0.0073853 & Srcin 1 & SRC kinase signaling inhibitor 1 \\
\hline 10459084 & -1.55 & 0.0168555 & Synpo & synaptopodin \\
\hline 10507347 & -1.80 & 0.031309 & Tesk2 & testis-specific kinase 2 \\
\hline 10504817 & -2.28 & 0.0027627 & Tgfbr1 & transforming growth factor, beta receptor I \\
\hline 10355806 & -1.57 & 0.0437603 & Tuba4a & tubulin, alpha $4 \mathrm{~A}$ \\
\hline 10408613 & -1.74 & 0.0023515 & Tubb2b & tubulin, beta $2 \mathrm{~B}$ class IIB \\
\hline 10576332 & -7.73 & 0.0008025 & Tubb3 & tubulin, beta 3 class III \\
\hline 10452295 & -13.79 & 0.0007598 & Tubb4a & tubulin, beta $4 \mathrm{~A}$ class IVA \\
\hline 10450605 & -1.55 & 0.0220591 & Tubb5 & tubulin, beta 5 class I \\
\hline 10446253 & -2.40 & 0.0030188 & Vav1 & vav 1 oncogene \\
\hline
\end{tabular}


TABLE 2: Continued

\begin{tabular}{|c|c|c|c|c|}
\hline ID & $\begin{array}{l}\text { Fold } \\
\text { change }\end{array}$ & adj.P.Val & $\begin{array}{l}\text { Gene } \\
\text { symbol }\end{array}$ & Gene description \\
\hline 10362717 & -2.82 & 0.00025 & Wasf1 & WAS protein family, member 1 \\
\hline 10483698 & -2.16 & 0.0004667 & Wipf1 & WAS/WASL interacting protein family, member 1 \\
\hline 10603440 & -1.74 & 0.0052575 & Was & Wiskott-Aldrich syndrome homolog (human) \\
\hline \multicolumn{5}{|c|}{ Response to hypoxia and oxidative stress } \\
\hline 10480734 & -3.25 & 0.0483629 & Ptgds & prostaglandin D2 synthase (brain) \\
\hline 10501199 & -2.76 & 0.003673 & Gstm7 & Glutathione S-transferase, mu 7 \\
\hline 10385583 & -2.57 & 0.0015118 & Ltc4s & leukotriene C4 synthase \\
\hline 10545101 & -2.34 & 0.0021426 & Hpgds & hematopoietic prostaglandin $\mathrm{D}$ synthase \\
\hline 10515090 & -2.24 & 0.0050272 & Cdkn2c & cyclin-dependent kinase inhibitor 2C (p18, inhibits CDK4) \\
\hline 10376201 & -2.06 & 0.0135463 & Gpx3 & glutathione peroxidase 3 \\
\hline 10384725 & -2.01 & 0.0231887 & Rel & reticuloendotheliosis oncogene \\
\hline 10363000 & 1.53 & 0.0108136 & Gpx4 & glutathione peroxidase 4 \\
\hline 10443463 & 1.53 & 0.0265879 & Cdkn1a & cyclin-dependent kinase inhibitor 1A (P21) \\
\hline 10545045 & 1.56 & 0.0157857 & Fam13a & family with sequence similarity 13 , member A \\
\hline 10467921 & 1.57 & 0.0166023 & Chuk & conserved helix-loop-helix ubiquitous kinase \\
\hline 10492428 & 1.58 & 0.0049631 & Tiparp & TCDD-inducible poly(ADP-ribose) polymerase \\
\hline 10515007 & 1.65 & 0.0284022 & Gpx7 & glutathione peroxidase 7 \\
\hline 10595148 & 1.67 & 0.0128636 & Gsta2 & glutathione S-transferase, alpha 2 (Yc2) \\
\hline 10520862 & 1.68 & 0.006082 & Fosl2 & fos-like antigen 2 \\
\hline 10571274 & 1.69 & 0.0302501 & Gsr & glutathione reductase \\
\hline 10485466 & 1.69 & 0.0040562 & Cat & catalase \\
\hline 10345065 & 1.74 & 0.0262016 & Gsta3 & glutathione S-transferase, alpha 3 \\
\hline 10382243 & 1.79 & 0.006033 & Gna13 & guanine nucleotide binding protein, alpha 13 \\
\hline 10370013 & 1.85 & 0.003188 & Gstt2 & glutathione $S$-transferase, theta 2 \\
\hline 10488879 & 1.92 & 0.0016807 & Gss & glutathione synthetase \\
\hline 10419198 & 1.94 & 0.0048617 & Ero1l & ERO1-like (S. cerevisiae) \\
\hline 10547641 & 1.97 & 0.0042575 & Slc2a3 & $\begin{array}{l}\text { solute carrier family } 2 \text { (facilitated glucose transporter), mem- } \\
\text { ber } 3\end{array}$ \\
\hline 10540472 & 2.00 & 0.0236792 & Bhlhe40 & basic helix-loop-helix family, member e 40 \\
\hline 10365260 & 2.08 & 0.0110414 & Txnrd 1 & thioredoxin reductase 1 \\
\hline 10501222 & 2.17 & 0.0098926 & Gstm2 & glutathione S-transferase, mu 2 \\
\hline 10495763 & 2.22 & 0.0010623 & Gclm & glutamate-cysteine ligase, modifier subunit \\
\hline 10478890 & 2.34 & 0.0018744 & Cebpb & CCAAT/enhancer binding protein $(\mathrm{C} / \mathrm{EBP})$, beta \\
\hline 10460585 & 2.38 & 0.0050272 & Fosl1 & fos-like antigen 1 \\
\hline 10501235 & 2.41 & 0.0170212 & Gstm4 & glutathione S-transferase, mu 4 \\
\hline 10545658 & 2.45 & 0.0031974 & Wdr54 & WD repeat domain 54 \\
\hline
\end{tabular}


TABLE 2: Continued

\begin{tabular}{|c|c|c|c|c|}
\hline ID & $\begin{array}{l}\text { Fold } \\
\text { change }\end{array}$ & adj.P.Val & $\begin{array}{l}\text { Gene } \\
\text { symbol }\end{array}$ & Gene description \\
\hline 10480035 & 2.59 & 0.0015395 & Pfkfb3 & 6-phosphofructo-2-kinase/fructose-2,6-biphosphatase 3 \\
\hline 10563338 & 2.91 & 0.0089732 & Ppp1r15a & protein phosphatase 1 , regulatory (inhibitor) subunit $15 \mathrm{~A}$ \\
\hline 10572897 & 3.17 & 0.0015395 & Hmox1 & heme oxygenase (decycling) 1 \\
\hline 10451198 & 3.48 & 0.0005288 & Vegfa & vascular endothelial growth factor A \\
\hline 10556297 & 3.55 & 0.0097619 & Adm & adrenomedullin \\
\hline 10545130 & 3.82 & 0.0003107 & Gadd45a & growth arrest and DNA-damage-inducible 45 alpha \\
\hline 10458894 & 5.91 & 0.0115852 & Lox & lysyl oxidase \\
\hline 10568369 & 6.02 & 0.0001009 & Cox6a2 & cytochrome c oxidase, subunit VI a, polypeptide 2 \\
\hline 10567995 & 8.32 & 0.0001009 & Nupr1 & nuclear protein 1 \\
\hline 10450038 & 8.60 & 0.0001798 & Angptl4 & angiopoietin-like 4 \\
\hline \multicolumn{5}{|c|}{$\begin{array}{l}\text { A list of genes that were down-, respectively up-regulated in PV-KO ependymal-cell extracts of DIV21-OHSCs as compared to their wild- } \\
\text { type counterparts, as resulted in a whole-transcriptome analysis. Headers include the Affymetrix gene ID, the fold-change value (negative val } \\
\text { ues meaning down-regulation in the PV-KO as compared to the wild-type, positive fold change values up-regulation, respectively), adjusted } \\
P \text { value, the gene symbol and gene description. }\end{array}$} \\
\hline
\end{tabular}

layer. These findings could implicate that in vivo lesioning of the brain parenchyma and lateral ventricle wall induces PVexpression not only in ependymal cells but also in other glial cell types adjacent to the injury that might participate in the formation of a glial scar. In addition, the fact that 6 weeks post-injury PV-expression was still present in the ependymal layer adjacent to the lesion implicates that the upregulation of PV in ependymal cells upon injury lasts for a relatively long time after the injury. This suggests that the tissue repair and healing, resp. reuniting of the ependymal and parenchymal wound rims is a fairly long process and requires a longlasting remodeling of the cells taking part in this procedure.

To ascertain whether the injury-induced increase in the number of PV-expressing cells in the wild-type animals and of the EGFP-expressing ones in the PV-KO/EGFP mice was a result of proliferation, the in vivo BrdU-based approach was instrumented. Mice received cumulative BrdU-injections (24 h and $3 \mathrm{~h}$ prior to sacrifice), and the number of BrdU+ cells were counted in coronal brain sections. Although numerous BrdU-positive nuclei were observed close to the lesion and to the ependymal layer, most of the proliferating cells were encountered at some distance from the latter. We thus conclude that the immunoreactivity for PV that was observed in the ependymal cells of the lateral ventricle wall and in those surrounding the lesion resulted from the de novo expression of the $\mathrm{CaBP}$ rather than from cell proliferation. The numerical density of BrdU-positive nuclei around the lesion was lower in the PV-KO/EGFP mice than in their wild-type counterparts
(55.5 cells \pm 13.5 in WT vs. $33.4 \pm 11.6$ in PV-KO/EGFP in the VZ lesion, $P=0.00013$, Student's $t$ test; 82.6 cells \pm 17.3 in WT vs. 50.1 cells \pm 16.0 in PV-KO/EGFP in the lesion and surroundings, $P=0.00002$ ), whereas that of progenitor cells in the SVZ was similar in each strain (43.0 cells \pm 6.8 in WT vs. 43.0 cells \pm 5.8 in PV-KO, $P=0.98$ ) (Fig. $8 \mathrm{~K})$. These findings indicate impairment of the PV-KO/EGFP mice in the post-injury cell proliferation that is needed for the formation of a glial scar. Taking together these results and our previous observations that the remodeling and maintenance of ependymal clusters is impaired in the OHSCs of the PV-KO mice, we conclude that parvalbumin contributes to the reorganization of ependymal cells following injury.

\section{PV-deficient Mice Exhibit More Severe Ventricular Enlargement Following Low-dose Intraventricular Neuraminidase Injection}

Based on the observation of others (Luo et al., 2008; Shook et al., 2013) indicating that intraventricular injection of neuraminidase leads to ependymal denudation and ventriculomegaly, we wondered whether PV also plays a role in nontraumatic experimental paradigm. Neuraminidase cleaves glycosidic linkages of adherens junctions from the surface of ependymal cells, thereby resulting in denudation of the ependymal layer (Grondona et al., 1996). High concentration of neuraminidase $\left(1 \mu \mathrm{L}\right.$ of $\left.100-500 \mathrm{ng} \mu \mathrm{L}^{-1}\right)$ was shown to induce the denudation of large ependymal areas and to result in extensive ependymal loss and gliosis along the ventricles 

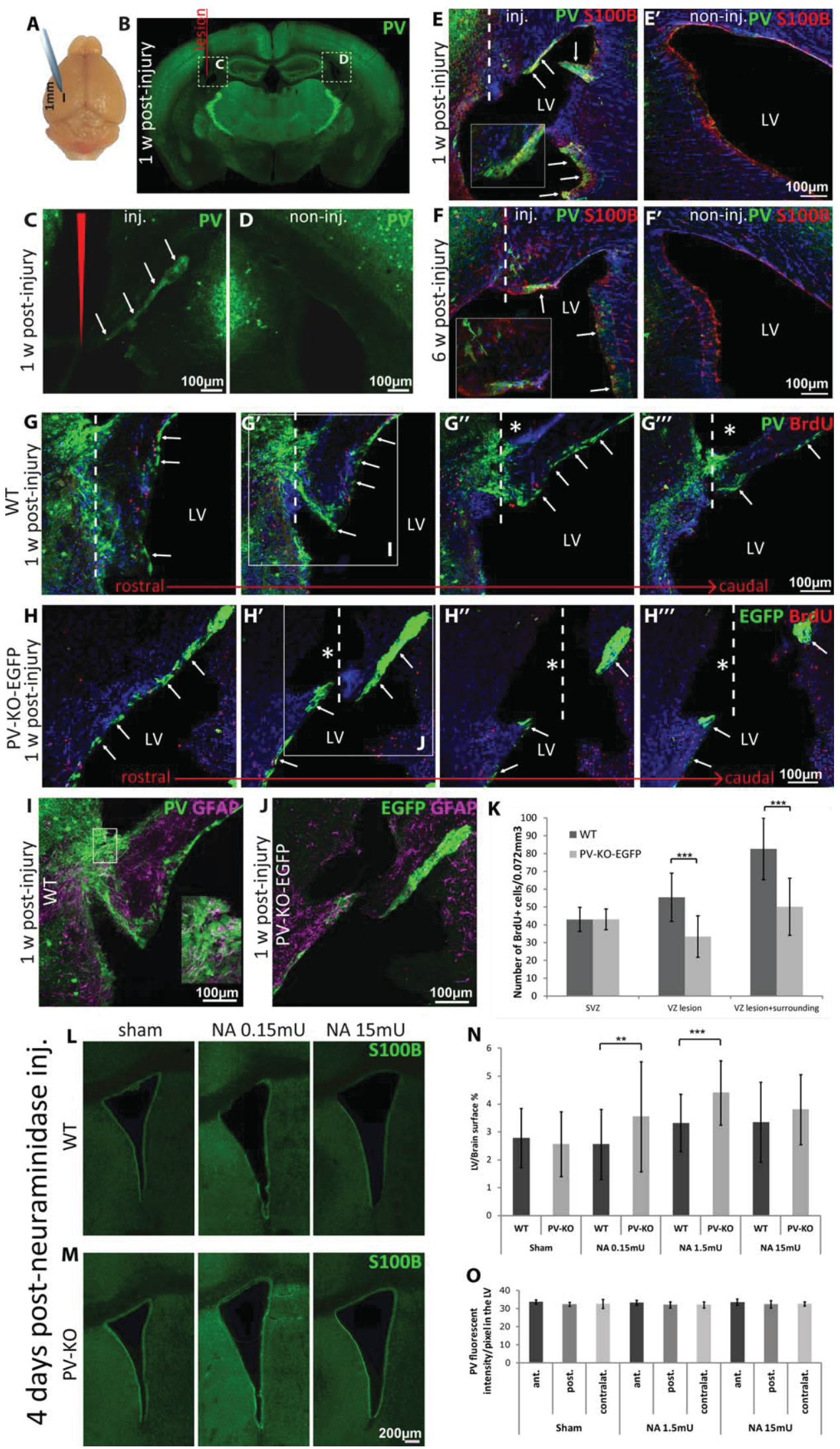

FIGURE 8 
(Luo et al., 2008), whereas mild denudation by lower dose of neuraminidase $\left(1 \mu \mathrm{L}\right.$ of $10 \mathrm{ng} \mu \mathrm{L}^{-1}$ or $\left.10-50 \mathrm{mU} \mu \mathrm{L}^{-1}\right)$ is comparable to the situation found in aged murine and human brain (Shook et al., 2013), with moderate ventriculomegaly and ventricular gliosis. Very low dose of neuraminidase $\left(1 \mu \mathrm{L}\right.$ of $\left.1 \mathrm{ng} \mu \mathrm{L}^{-1}\right)$ was shown to cause no visible ependymal loss (Luo et al., 2008). The degree of ventriculomegaly and ventricular gliosis following denudation therefore correspond to the degree of ependymal cell loss. $1 \mu \mathrm{L}$ neuraminidase of $15,1.5$, and $0.15 \mathrm{mU}_{\mu \mathrm{L}}^{-1}$ concentration was injected into the lateral ventricles of young adult wild-type (C57BL/6) and PV-KO mice to mimic ependymal denudation, whereas sham animals received $1 \mu \mathrm{l}$ sterile saline solution. Animals were perfused 4 days after a single intraventricular injection. We performed S100ß-, GFAP-, and PV-immunostainings to reveal the state of the ependymal layer and the degree of potential ventricular gliosis. We found no increase in GFAP staining around the ventricles in neuraminidase injected mice compared with sham animals (data not shown), which is probably due to the short time allowed after the injection. We observed ependymal cell loss that was in accordance to previous findings (Luo et al., 2008). There were no significant differences in the intensities of S100ß- and GFAP-staining in and around the ependymal layer when we compared PV-KO and wild-type animals of the same treatment group. We also measured the size of the ventricles to estimate the degree of ependymal dysfunction caused by the loss of intact ependymal lining (Fig. 8L,M). We found that the highest dose of neuraminidase injection $(15 \mathrm{mU})$ caused a similar ventricular enlargement in both wild-type and PV-KO mice (Fig. 8L-N). However, lower doses of neuraminidase $(1.5$ and $0.15 \mathrm{mU})$ caused a significantly more severe ventriculomegaly in PV-KO mice than did in their wild-type counterparts (Fig. 8L-N). Together, these findings show that low doses of neuraminidase which were described to cause subminimal damage to the ependymal layer, in the absence of PV lead to serious consequences. However, by PV-immunohistochemistry we failed to detect an up-regulation of this $\mathrm{CaBP}$ in the ependymal layer following varying doses of neuraminidase compared with the ependyma of sham-injected animals (Fig. 8O). On the basis of these findings, we conclude that in vivo enzymatic dissociation of ependymal cells by neuroaminidase does not trigger parvalbumin-expression.

FIGURE 8: Unilateral in vivo stereotactic injury of the hippocampus and lateral ventricle in adult wild-type and PV-KO/EGFP mice induces PV-, resp. EGFP-expression adjacent to the lesion, whereas neuraminidase-triggered denudation does not induce it. (A) Schematic image illustrates the lesion site from a dorsal view of the mouse brain. The stereotactic coordinates of the lesion were chosen to injure the lateral ventricle wall at the level of the ventricular zone (VZ) of the hippocampus in a 1-mm-long parasagittal section from Bregma -1.0

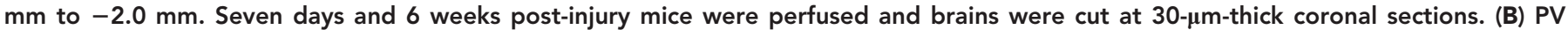
was revealed immunohistochemically and visualized with a digital slide scanner. The location of the stab lesion is indicated by a red line. (C) Confocal z-stack projection image shows that on the injured side (inj.), the ependymal layer adjacent to the lesion shows PVimmunoreactivity. (D) The ependymal layer of the non-injured side (non-inj.) is immunonegative for PV (confocal z-stack projection). (E$\left.E^{\prime}\right)$ Confocal z-stack projections of 1-week-post-injury coronal sections of the injured and non-injured side reveal PV-immunoreactivity (white arrows) in the ependymal layer around the lesion, whereas the non-injured ependymal layer manifests no or minimal PVimmunostaining. Ependymal layer is marked by $\mathbf{S 1 0 0 \beta}$, dashed line indicates the location of stab lesion. Inset shows PV-immunopositive ependymal cells close to the stab lesion at high magnification. (F-F') Confocal z-stack projections of 6-weeks-post-injury coronal sections reveal PV-immunoreactivity in the ependymal layer (white arrows) in the injured side, whereas the non-injured ependymal layer remains PV-immunonegative. Inset shows PV-positive ependymal cells in the ependymal layer (labeled by S100ß) at high magnification. Single PV+ cells can be found in the brain parenchyma at the site of the lesion just above the ependymal layer. (G-G"') A rostrocaudal series of 1-week-post-injury coronal sections visualized by confocal laser microscopy at the rostral level of the injury in wild-type (C57BL/6) mice immunostained for BrdU and PV reveals upregulation of PV in ependymal cells adjacent to the lesion and in a subset of cells around the injury (white arrows). Dashed line indicates the position of the lesion. The stab lesion (white star) seems partly repaired/ closed by a mass of numerous cells, most of which are PV-positive. The boxed region is shown with corresponding GFAP staining in (I). $\left(\mathrm{H}-\mathrm{H}^{\prime \prime \prime}\right.$.) One week following injury, PV-KO/EGFP ependymal cells acquire strong EGFP-expression adjacent to the lesion (white arrows), as shown by confocal laser micrographs of a rostrocaudal series of coronal sections at the rostral level of the injury immunostained for BrdU and EGFP. There is no sign of reunion of the disrupted ependymal wound rims and the lesion (white star) is unclosed. Boxed region is shown with corresponding GFAP staining in (J). (I) GFAP immunostaining was performed to reveal reactive astrocytes around the lesion. Astrocytes are present in the wild-type scar and around the ependymal layer, the inset shows at higher magnification that some cells are co-labeled for GFAP and PV. (J) In the PV-KO-EGFP wound, numerous GFAP+ cells can be found around the ependymal lesion, but there is no visible glial scar tissue. (K) The number of BrdU-positive cell nuclei was counted per $0.072 \mathrm{~mm}^{3}$ in 13 consecutive coronal sections at the level of the injury in three regions: in the SVZ, in the lesion zone, and in the lesion with the surrounding parenchyma. Visibly, more dividing cells are present around the lesion in wild-type than in PV-KO-EGFP ( $P$ calculated by Student's $t$ test), whereas the number of dividing cell nuclei remains similar in the SVZ further away from the lesion site. ( $L$ and M) Larger lateral ventricles develop 4 days after varying doses of neuraminidase injection in both wild-type and PV-KO mice compared with saline-injected (sham) animals. (N) The grade of enlargement seems similar after the injection of $15 \mathrm{mU}$ neuraminidase; however, lower doses of the enzyme $(0.15$ and $1.5 \mathrm{mU})$ resulted in a more explicit ventricular enlargement in PV-KO mice than in their wild-type counterparts. (O) The mean fluorescent intensity/pixel of PV-immunostaining around the lateral ventricle in sham- and neuraminidase-injected wild-type mice is similar in all animals. Visibly, neuraminidase injection did not result in the up-regulation of the PV-immunostaining. Error bars show SEM. (LV: lateral ventricle; $\left.{ }^{\star \star P}<0.005 ;{ }^{\star \star \star} P<0.0005\right)$. 


\section{Discussion}

Manipulations that disrupt the integrity of the ependymal layer, such as the preparation of OHSCs for in vitro maintenance or the infliction of a stab-wound to the ventricular wall in vivo, induce the rapid de novo expression of the EF-hand calcium-binding protein parvalbumin in ependymal cells. Scratches inflicted to ependymal-cell clusters in OHSCs result in PV-up-regulation, increased ependymal-cell motility and adhesion, followed by considerably better scratch repair ability in wild-type compared with PV-KO mice. Blockage of the inflammatory regulator transcription factor NF-KB inhibits the synthesis of PV in ependymal cells, whilst exposure to antioxidants diminishes it. Our findings suggest that injury and injury-related repair mechanisms induce, either directly or indirectly, the de novo expression of PV in ependymal cells, increasing their motility and adhesion, and promoting reepithelialization of the scratch and of the wound.

The response of the central nervous system (CNS) to injury is of a complex nature and involves the participation of numerous soluble factors and cell types. Initially, the blood-brain barrier is violated, as a consequence of which leukocytes, macrophages and lymphocytes invade the immunoprivileged compartment (Kawano et al., 2012). These cells secrete cytokines and chemokines, which trigger the resident populations of microglia, astrocytes, and oligodendrocyte precursors to lay down a glial scar around the lesion (Kawano et al., 2012).

Only a few studies have addressed the impact on ependymal cells of traumatic brain injury that directly compromises the integrity of the eponymous layer. Post-stroke ependymal cells acquire reactive-astrocyte-like phenotype, express de novo GFAP and extend long cytoplasmic processes (Young et al., 2013). Upon injury, ependymal cells also exhibit a pronounced fate plasticity (Carlen et al., 2009; Nomura et al., 2010). Nevertheless, ependymal cells, unlike other epithelial layers, are considered non-regenerative as they do not divide in the adult brain (Bruni, 1998; Luo et al., 2008; Spassky et al., 2005). Intraventricular injection of neuraminidase results in ependymal denudation, ventricular gliosis and irreversible ependymal loss followed by ventriculomegaly (Luo et al., 2008).

Here, we introduced an experimental model that combined traumatic parenchymal brain injury with mechanical disruption of the ependymal layer. The de novo expression of $\mathrm{PV}$ in ependymal cells was observed to facilitate the reclosure of the lesion in vivo and the scratch-wound closure and adhesion of ependymal cells in vitro. Consequently, we suspected that the de novo expression of $\mathrm{PV}$ in ependymal cells might play a role in injury-induced processes that favor tissue remodeling, wound closure and eventually scar formation. A comparative whole-transcriptome analysis of the reactive ependymal-niche extracts of wild-type and PV-KO OHSCs revealed that in the latter, the expression levels of genes that are implicated in cytoskeletal remodeling, cell motility and cell adhesion were decreased, whereas those that are implicated in hypoxic damage were elevated. Hence, the absence of PV might reduce mobility and adhesion and enhance the vulnerability of ependymal cells to injury-induced hypoxic damage and compromise their capacity for tissue remodeling and wound closure.

The stem-cell attributes of ependymal cells are still a subject of debate (Chojnacki et al., 2009). It is believed that lateral ventricle wall ependymal cells lack self-renewal potential, whereas spinal cord ependymal cells possess certain stem cell properties; however, in vivo they generate progeny only upon injury and not under physiological conditions (Meletis et al., 2008; Pfenninger et al., 2011). In our own experiments with OHSCs, co-localization of the PV-expressing ependymal cells with the proliferation marker Ki67 was hardly ever observed. Similarly in vivo, the infliction of a stab-wound did not result in the labeling of PV-expressing ependymal cells with BrdU. These findings indicate that the subpopulation of injury-reactive, PV-expressing ependymal cells is post-mitotic.

Cells of the ependymal layer interdigitate via plasmalemmal adherens junctions (Del Bigio, 2010), and ankyrin-3 in the lateral membrane (Paez-Gonzalez et al., 2011), which may play a role in the "sealing of the epithelium." In the OHSCs of PV-KO mice, the junctions and the interdigitations of the ependymal cells were loosened. This phenomenon correlated with the observed down-regulation of a set of cellular junction-related genes. These included not only the ankyrin-3 encoding gene $A n k 3$, but also adherens-junctionspecific genes, such as cadherins and protocadherins and the tight-junction-specific ZO-1 protein-encoding gene Tjp 1. We also observed striking differences in the morphology of the injury-reactive ependymal cells following in vivo lesioning: the ependymal cells of the PV-KO mice remained in situ and did not display a radial phenotype, whereas PV-expressing ependymal cells of the wild-type mice protruded long cytoplasmic processes (Fig. 8I,J).

Because the main described function of PV is calciumbuffering (Schwaller 2010), the differences in the phenotypic and the migrating properties of the ependymal cells between wild-type and PV-KO strains of mice suggest that their motility and cytoskeletal remodeling are regulated by an as yet unidentified calcium-dependent process. This postulate accords with the finding that several of the genes that are implicated in the control of Cdc42/Rac1/Rho-signaling pathway, which regulates the motility of cells and changes in their shape (Bokoch, 2003; Pollard and Borisy, 2003), were downregulated in the PV-KO mice (e.g., Pak1, Vav1, Wasfl, Arpc1a, Arpc1b, and Rap1a). In contrast to $S 100 \beta$, which acts 
as a $\mathrm{Ca}^{2+}$-sensor and has a relatively low affinity for $\mathrm{Ca}^{2+}$ under physiologic ionic conditions (Donato, 1999), $\mathrm{PV}$ is classified as a slow-onset $\mathrm{Ca}^{2+}$-buffer, which has a high binding affinity for the intracellular cation (Schwaller, 2010). By the sequestration of calcium within subcellular compartments, CaBPs facilitate the generation of $\left[\mathrm{Ca}^{2+}\right]_{\mathrm{i}}$ gradients (Schwaller, 2010). The maintenance of these polarized gradients in $\left[\mathrm{Ca}^{2+}\right]_{\mathrm{i}}$ is vital for many biological functions (Wahl et al., 1992), including cell motility. The buffering capacity of PV might also facilitate the "quenching" of excessive amounts of calcium that flood cells during injury, mechanical stress, and the release of cytokines.

Our observation that the up-regulation of parvalbumin in ependymal cells contributes to their motility was anticipated by unrelated studies using other systems. In the fasttwitch muscles of mice, the transient binding of PV to intracellular calcium facilitates the rapid relaxation of the muscle fibers. As a consequence, in the muscles of PV-KO mice, the relaxation-time is prolonged (Schwaller et al., 1999), whereas in PV-transgenic muscles it is shortened (Muntener et al., 1995). A promoting effect of PV on cell motility has been observed also in cultured WiDr-cells that were transfected with PV-cDNA (Andressen et al., 1995). These cells display a higher capacity to undergo amoeboid-like movements than do their wild-type counterparts.

In neurons, PV plays a role not in their motility but in the regulation of their electrophysiology (Caillard et al., 2000; Collin et al., 2005; Muller et al., 2007; Vreugdenhil et al., 2003). Under experimental and pathologic conditions, the concentration of PV in neurons can be altered (Levitt et al., 2004). For example, the administration of ketamine provokes a loss of PV-immunoreactivity from GABA-ergic interneurons and a decrease in their inhibitory potency by increasing the level of the pro-inflammatory cytokine IL-6 in the brain, which activates the superoxide-producing enzyme NADPH oxidase (Behrens and Sejnowski, 2009; Powell et al., 2012). In murine models, treatment regimes that restore the redox balance, such as the administration of the antioxidant $N$-acetylcysteine, help to correct some of these deficits (Cabungcal et al., 2006; Kulak et al., 2013). As our own study has shown, ependymal cells react to the same inflammatory cytokines (e.g., IL-6) in a manner that differs basically from that of neurons, namely, by the de novo synthesis of PV. Cell-type-specific differences in the regulation of the Pvalb-promoter have not been reported, but have been documented for other CaBPs. In nerve cells, the calretinin-promoter contains a specific AP2-like element that assures a neuron-specific pattern of gene-expression (BillingMarczak et al., 2002). In colon cancer cells, butyrate downregulates the expression of calretinin (Haner et al., 2010), whereas in mesothelioma cells, none of these mechanisms influence its expression (Haner et al., 2010).
A role in protecting cells against deleterious increases in $\left[\mathrm{Ca}^{2+}\right]_{\mathrm{i}}$ (Schwaller et al., 2002) could underlie the de novo expression of PV in ependymal cells. In various experimental in vivo models, PV protected vulnerable neurons (Beers et al., 2001; Friedman and Segal, 2010; Nitsch et al., 1989; Van Den Bosch et al., 2002). In other instances, PVimmunoreactivity did not prevent neuronal cell death (Dijk and Kamphuis, 2004; Maetzler et al., 2004). Because PV constitutes only one of the many components of the calcium homeostasome (Berridge et al., 2003; Schwaller, 2012), its protective role may be masked in experimental models in vivo by the complexity of the physiological situation. Calretinin, another member of the same EF-hand family of CaBPs, has been shown to have a convincing protective effect on cells. This CaBP is expressed in colonic cancer cells, and in reactive as well as in neoplastic mesothelial cells. In both cell types, calretinin promotes growth and survival, and its downregulation by the administration of antisense oligodeoxynucleotides (Gander et al., 1996), or by treatment with lentiviral-mediated shRNA (Blum and Schwaller, 2013), respectively, leads to apoptotic cell death.

We have here shown that the PV-positive ependymal cells of wild-type mice adapt better to the altered conditions following mechanical injury than do the counterparts of PV$\mathrm{KO}$ ones, indicating that this $\mathrm{CaBP}$ benefits the ependymal cells.

By showing that the calcium-binding protein parvalbumin plays an unsuspected role in the response of ependymal cells, the findings of this study furnish a basis for improving our understanding of the cascade of events that is triggered by traumatic brain injury.

\section{Acknowledgment}

Grant sponsor: Swiss National Foundation; Grant number: NF31003A_144036/1; and the Canton of Fribourg.

The authors thank Jonas Frisén, Franck Girard, Lavinia Albéri, Alessandra Scotti, and Anna Jazwinska for their helpful comments on the manuscript, likewise Alexandre Babalian, Alessandro Bilella, Brigitte Scolari, Laurent Falquet, Walter Blum, Valérie Salicio, Laurence Clement, Christiane Marti, Marlene Sanchez, Simone Eichenberger, Joel Jovanovic, and Emanuel Lauber for their technical support.

\section{References}

Andressen C, Gotzos V, Berchtold MW, Pauls TL, Schwaller B, Fellay B, Celio MR. 1995. Changes in shape and motility of cells transfected with parvalbumin cDNA. Exp Cell Res 219:420-426.

Beers DR, Ho BK, Siklos L, Alexianu ME, Mosier DR, Mohamed AH, Otsuka Y, Kozovska ME, McAlhany RE, Smith RG, Appel SH. 2001. Parvalbumin overexpression alters immune-mediated increases in intracellular calcium, and delays disease onset in a transgenic model of familial amyotrophic lateral sclerosis. J Neurochem 79:499-509. 
Behrens MM, Sejnowski TJ. 2009. Does schizophrenia arise from oxidative dysregulation of parvalbumin-interneurons in the developing cortex? Neuropharmacology 57:193-200.

Berridge MJ, Bootman MD, Roderick HL. 2003. Calcium signalling: Dynamics, homeostasis and remodelling. Nat Rev Mol Cell Biol 4:517-529.

Billing-Marczak K, Buzanska L, Winsky L, Nowotny M, Rudka T, Isaacs K, Belin MF, Kuznicki J. 2002. AP2-like cis element is required for calretinin gene promoter activity in cells of neuronal phenotype differentiated from multipotent human cell line DEV. Biochim Biophys Acta 1577:412-420.

Block ER, Klarlund JK. 2008. Wounding sheets of epithelial cells activates the epidermal growth factor receptor through distinct short- and long-range mechanisms. Mol Biol Cell 19:4909-4917.

Blum W, Schwaller B. 2013. Calretinin is essential for mesothelioma cell growth/survival in vitro: A potential new target for malignant mesothelioma therapy? Int J Cancer 133:2077-2088.

Bokoch GM. 2003. Biology of the p21-activated kinases. Annu Rev Biochem 72:743-781

Bruni JE. 1998. Ependymal development, proliferation, and functions: A review. Microsc Res Tech 41:2-13.

Cabungcal JH, Nicolas D, Kraftsik R, Cuenod M, Do KQ, Hornung JP. 2006. Glutathione deficit during development induces anomalies in the rat anterior cingulate GABAergic neurons: Relevance to schizophrenia. Neurobiol Dis 22: 624-637.

Caillard O, Moreno H, Schwaller B, Llano I, Celio MR, Marty A. 2000. Role of the calcium-binding protein parvalbumin in short-term synaptic plasticity. Proc Natl Acad Sci USA 97:13372-13377

Capilla-Gonzalez V, Cebrian-Silla A, Guerrero-Cazares H, Garcia-Verdugo JM, Quinones-Hinojosa A. 2014. Age-related changes in astrocytic and ependymal cells of the subventricular zone. Glia 62:790-803.

Carlen M, Meletis K, Goritz C, Darsalia V, Evergren E, Tanigaki K, Amendola M, Barnabe-Heider F, Yeung MS, Naldini L, Honjo T, Kokaia Z, Shupliakov O, Cassidy RM, Lindvall O, Frisén J. 2009. Forebrain ependymal cells are Notchdependent and generate neuroblasts and astrocytes after stroke. Nat Neurosci 12:259-267.

Celio MR. 1990. Calbindin D-28k and parvalbumin in the rat nervous system. Neuroscience 35:375-475.

Celio MR, Heizmann CW. 1981. Calcium-binding protein parvalbumin as a neuronal marker. Nature 293:300-302.

Chen G, Racay P, Bichet S, Celio MR, Eggli P, Schwaller B. 2006. Deficiency in parvalbumin, but not in calbindin D-28k upregulates mitochondrial volume and decreases smooth endoplasmic reticulum surface selectively in a peripheral, subplasmalemmal region in the soma of Purkinje cells. Neuroscience 142:97-105.

Chojnacki AK, Mak GK, Weiss S. 2009. Identity crisis for adult periventricular neural stem cells: Subventricular zone astrocytes, ependymal cells or both? Nat Rev Neurosci 10:153-163.

Cocchia D. 1981. Immunocytochemical localization of S-100 protein in the brain of adult rat. An ultrastructural study. Cell Tissue Res 214:529-540.

Collin T, Chat M, Lucas MG, Moreno H, Racay P, Schwaller B, Marty A, Llano I. 2005. Developmental changes in parvalbumin regulate presynaptic $\mathrm{Ca} 2+$ signaling. J Neurosci 25:96-107.

Coskun V, Wu H, Blanchi B, Tsao S, Kim K, Zhao J, Biancotti JC, Hutnick L, Krueger RC Jr., Fan G, de Vellis J, Sun YE. 2008. CD133+ neural stem cells in the ependyma of mammalian postnatal forebrain. Proc Natl Acad Sci USA 105: 1026-1031.

Danilov Al, Gomes-Leal W, Ahlenius H, Kokaia Z, Carlemalm E, Lindvall O. 2009. Ultrastructural and antigenic properties of neural stem cells and their progeny in adult rat subventricular zone. Glia 57:136-152.

Del Bigio MR. 2010. Ependymal cells: Biology and pathology. Acta Neuropathol 119:55-73.

Dijk F, Kamphuis W. 2004. An immunocytochemical study on specific amacrine cell subpopulations in the rat retina after ischemia. Brain Res 1026:205-217.
Donato R. 1999. Functional roles of S100 proteins, calcium-binding proteins of the EF-hand type. Biochim Biophys Acta 1450:191-231.

Donato R, Sorci G, Riuzzi F, Arcuri C, Bianchi R, Brozzi F, Tubaro C, Giambanco I. 2009. S100B's double life: Intracellular regulator and extracellular signal. Biochim Biophys Acta 1793:1008-1022.

Fallon J, Reid S, Kinyamu R, Opole I, Opole R, Baratta J, Korc M, Endo TL, Duong A, Nguyen G, Karkehabadhi M, Twardzik D, Patel S, Loughlin S. 2000. In vivo induction of massive proliferation, directed migration, and differentiation of neural cells in the adult mammalian brain. Proc Natl Acad Sci USA 97: 14686-14691.

Friedman LK, Segal M. 2010. Early exposure of cultured hippocampal neurons to excitatory amino acids protects from later excitotoxicity. Int J Dev Neurosci 28:195-205.

Gähwiler BH, Thompson SM, Muller D. 2001. Preparation and maintenance of organotypic slice cultures of CNS tissue. Curr Protoc Neurosci Chapter 6:11.

Gajera CR, Emich H, Lioubinski O, Christ A, Beckervordersandforth-Bonk R, Yoshikawa K, Bachmann S, Christensen El, Gotz M, Kempermann G, Peterson AS, Willnow TE, Hammes A. 2010. LRP2 in ependymal cells regulates BMP signaling in the adult neurogenic niche. J Cell Sci 123 (Part 11):1922-1930.

Gander JC, Gotzos V, Fellay B, Schwaller B. 1996. Inhibition of the proliferative cycle and apoptotic events in WiDr cells after down-regulation of the calcium-binding protein calretinin using antisense oligodeoxynucleotides. Exp Cell Res 225:399-410.

Ghosh S, May MJ, Kopp EB. 1998. NF-kappa B and Rel proteins: Evolutionarily conserved mediators of immune responses. Annu Rev Immunol 16:225260 .

Gleason D, Fallon JH, Guerra M, Liu JC, Bryant PJ. 2008. Ependymal stem cells divide asymmetrically and transfer progeny into the subventricular zone when activated by injury. Neuroscience 156:81-88.

Gregg C, Weiss S. 2003. Generation of functional radial glial cells by embryonic and adult forebrain neural stem cells. J Neurosci 23:11587-11601.

Grondona JM, Perez-Martin M, Cifuentes M, Perez J, Jimenez AJ, PerezFigares JM, Fernandez-Llebrez P. 1996. Ependymal denudation, aqueductal obliteration and hydrocephalus after a single injection of neuraminidase into the lateral ventricle of adult rats. J Neuropathol Exp Neurol 55:999-1008.

Haner K, Henzi T, Pfefferli M, Kunzli E, Salicio V, Schwaller B. 2010. A bipartite butyrate-responsive element in the human calretinin (CALB2) promoter acts as a repressor in colon carcinoma cells but not in mesothelioma cells. J Cell Biochem 109:519-531.

Jacquet BV, Salinas-Mondragon R, Liang H, Therit B, Buie JD, Dykstra M, Campbell K, Ostrowski LE, Brody SL, Ghashghaei HT. 2009. FoxJ1-dependent gene expression is required for differentiation of radial glia into ependymal cells and a subset of astrocytes in the postnatal brain. Development 136: 4021-4031.

Kawano H, Kimura-Kuroda J, Komuta Y, Yoshioka N, Li HP, Kawamura K, Li Y, Raisman G. 2012. Role of the lesion scar in the response to damage and repair of the central nervous system. Cell Tissue Res 349:169-180.

Kazanis I, Lathia J, Moss L, ffrench-Constant C. 2008. The neural stem cell microenvironment. In: StemBook, ed. The Stem Cell Research Community, Cambridge (MA): Harvard Stem Cell Institute; doi: 10.3824/stembook.1.15.1, http://www.stembook.org.

Kokovay E, Shen Q, Temple S. 2008. The incredible elastic brain: How neural stem cells expand our minds. Neuron 60:420-429.

Kriegstein A, Alvarez-Buylla A. 2009. The glial nature of embryonic and adult neural stem cells. Annu Rev Neurosci 32:149-184.

Kulak A, Steullet P, Cabungcal JH, Werge T, Ingason A, Cuenod M, Do KQ. 2013. Redox dysregulation in the pathophysiology of schizophrenia and bipolar disorder: insights from animal models. Antioxid Redox Signal 18:14281443.

Levitt P, Eagleson KL, Powell EM. 2004. Regulation of neocortical interneuron development and the implications for neurodevelopmental disorders. Trends Neurosci 27:400-406. 
Lim DA, Tramontin AD, Trevejo JM, Herrera DG, Garcia-Verdugo JM, Alvarez-Buylla A. 2000. Noggin antagonizes BMP signaling to create a niche for adult neurogenesis. Neuron 28:713-726.

Liu X, Bolteus AJ, Balkin DM, Henschel O, Bordey A. 2006. GFAP-expressing cells in the postnatal subventricular zone display a unique glial phenotype intermediate between radial glia and astrocytes. Glia 54:394-410.

Lossi L, Alasia S, Salio C, Merighi A. 2009. Cell death and proliferation in acute slices and organotypic cultures of mammalian CNS. Prog Neurobiol 88: $221-245$

Luo J, Shook BA, Daniels SB, Conover JC. 2008. Subventricular zonemediated ependyma repair in the adult mammalian brain. J Neurosci 28: 3804-3813.

Maetzler W, Nitsch C, Bendfeldt K, Racay P, Vollenweider F, Schwaller B. 2004. Ectopic parvalbumin expression in mouse forebrain neurons increases excitotoxic injury provoked by ibotenic acid injection into the striatum. Exp Neurol 186:78-88.

Marques F, Sousa JC, Coppola G, Falcao AM, Rodrigues AJ, Geschwind DH, Sousa N, Correia-Neves M, Palha JA. 2009. Kinetic profile of the transcriptome changes induced in the choroid plexus by peripheral inflammation. J Cereb Blood Flow Metab 29:921-932.

Marques F, Sousa JC, Coppola G, Gao F, Puga R, Brentani H, Geschwind DH, Sousa N, Correia-Neves M, Palha JA. 2011. Transcriptome signature of the adult mouse choroid plexus. Fluids Barriers CNS 8:10.

Meletis K, Barnabe-Heider F, Carlen M, Evergren E, Tomilin N, Shupliakov O, Frisen J. 2008. Spinal cord injury reveals multilineage differentiation of ependymal cells. PLoS Biol 6:e182

Mirzadeh Z, Merkle FT, Soriano-Navarro M, Garcia-Verdugo JM, AlvarezBuylla A. 2008. Neural stem cells confer unique pinwheel architecture to the ventricular surface in neurogenic regions of the adult brain. Cell Stem Cell 3: 265-278.

Muller M, Felmy F, Schwaller B, Schneggenburger R. 2007. Parvalbumin is a mobile presynaptic $\mathrm{Ca} 2+$ buffer in the calyx of held that accelerates the decay of $\mathrm{Ca} 2+$ and short-term facilitation. J Neurosci 27:2261-2271.

Muntener M, Kaser L, Weber J, Berchtold MW. 1995. Increase of skeletal muscle relaxation speed by direct injection of parvalbumin cDNA. Proc Natl Acad Sci USA 92:6504-6508.

Nitsch C, Goping G, Klatzo I. 1989. Preservation of GABAergic perikarya and boutons after transient ischemia in the gerbil hippocampal CA1 field. Brain Res 495:243-252.

Nomura T, Goritz C, Catchpole T, Henkemeyer M, Frisen J. 2010. EphB signaling controls lineage plasticity of adult neural stem cell niche cells. Cell Stem Cell 7:730-743

Ostrowski LE, Hutchins JR, Zakel K, O'Neal WK. 2003. Targeting expression of a transgene to the airway surface epithelium using a ciliated cell-specific promoter. Mol Ther 8:637-645.

Paez-Gonzalez P, Abdi K, Luciano D, Liu Y, Soriano-Navarro M, Rawlins E, Bennett V, Garcia-Verdugo JM, Kuo CT. 2011. Ank3-dependent SVZ niche assembly is required for the continued production of new neurons. Neuron 71:61-75.

Pfenninger CV, Steinhoff C, Hertwig F, Nuber UA. 2011. Prospectively isolated CD133/CD24-positive ependymal cells from the adult spinal cord and lateral ventricle wall differ in their long-term in vitro self-renewal and in vivo gene expression. Glia 59:68-81

Pollard TD, Borisy GG. 2003. Cellular motility driven by assembly and disassembly of actin filaments. Cell 112:453-465.

Powell SB, Sejnowski TJ, Behrens MM. 2012. Behavioral and neurochemical consequences of cortical oxidative stress on parvalbumin-interneuron maturation in rodent models of schizophrenia. Neuropharmacology 62:1322-1331.

Ramirez-Castillejo C, Sanchez-Sanchez F, Andreu-Agullo C, Ferron SR, ArocaAguilar JD, Sanchez P, Mira H, Escribano J, Farinas I. 2006. Pigment epithelium-derived factor is a niche signal for neural stem cell renewal. Nat Neurosci 9:331-339.

Saeed Al, Sharov V, White J, Li J, Liang W, Bhagabati N, Braisted J, Klapa M, Currier T, Thiagarajan M, Sturn A, Snuffin M, Rezantsev A, Popov D, Ryltsov A, Kostukovich E, Borisovsky I, Liu Z, Vinsavich A, Trush V, Quackenbush J. 2003. TM4: A free, open-source system for microarray data management and analysis. Biotechniques 34:374-378.

Sawamoto K, Wichterle H, Gonzalez-Perez O, Cholfin JA, Yamada M, Spassky N, Murcia NS, Garcia-Verdugo JM, Marin O, Rubenstein JL, Tessier-Lavigne M, Okano H, Alvarez-Buylla A. 2006. New neurons follow the flow of cerebrospinal fluid in the adult brain. Science 311:629-632.

Schwaller B. 2010. Cytosolic Ca2+ buffers. Cold Spring Harb Perspect Biol 2: a004051.

Schwaller B. 2012. The regulation of a cell's $\mathrm{Ca}(2+)$ signaling toolkit: The $\mathrm{Ca}$ (2+) homeostasome. Adv Exp Med Biol 740:1-25.

Schwaller B, Dick J, Dhoot G, Carroll S, Vrbova G, Nicotera P, Pette D, Wyss A, Bluethmann H, Hunziker W, Celio MR. 1999. Prolonged contractionrelaxation cycle of fast-twitch muscles in parvalbumin knockout mice. Am J Physiol 276(2, Part 1):C395-C403.

Schwaller B, Meyer M, Schiffmann S. 2002. "New" functions for "old" proteins: The role of the calcium-binding proteins calbindin D-28k, calretinin and parvalbumin, in cerebellar physiology. Studies with knockout mice. Cerebellum 1:241-258.

Shook BA, Lennington JB, Acabchuk RL, Halling M, Sun Y, Peters J, Wu Q, Mahajan A, Fellows DW, Conover JC. 2013. Ventriculomegaly associated with ependymal gliosis and declines in barrier integrity in the aging human and mouse brain. Aging Cell 13:340-350.

Solbach S, Celio MR. 1991. Ontogeny of the calcium binding protein parvalbumin in the rat nervous system. Anat Embryol (Berl) 184:103-124.

Spassky N, Merkle FT, Flames N, Tramontin AD, Garcia-Verdugo JM, Alvarez-Buylla A. 2005. Adult ependymal cells are postmitotic and are derived from radial glial cells during embryogenesis. J Neurosci 25:10-18.

Stoppini L, Buchs PA, Muller D. 1991. A simple method for organotypic cultures of nervous tissue. J Neurosci Methods 37:173-182.

Subramanian A, Tamayo P, Mootha VK, Mukherjee S, Ebert BL, Gillette MA, Paulovich A, Pomeroy SL, Golub TR, Lander ES, Mesirov JP. 2005. Gene set enrichment analysis: A knowledge-based approach for interpreting genomewide expression profiles. Proc Natl Acad Sci USA 102:15545-15550.

Teramoto T, Qiu J, Plumier JC, Moskowitz MA. 2003. EGF amplifies the replacement of parvalbumin-expressing striatal interneurons after ischemia. J Clin Invest 111:1125-1132.

Van Den Bosch L, Schwaller B, Vleminckx V, Meijers B, Stork S, Ruehlicke T, Van Houtte E, Klaassen H, Celio MR, Missiaen L, Robberecht W, Berchtold MW. 2002. Protective effect of parvalbumin on excitotoxic motor neuron death. Exp Neurol 174:150-161.

Vreugdenhil M, Jefferys JG, Celio MR, Schwaller B. 2003. Parvalbumin-deficiency facilitates repetitive IPSCs and gamma oscillations in the hippocampus. J Neurophysiol 89:1414-1422.

Wahl M, Sleight RG, Gruenstein E. 1992. Association of cytoplasmic free Ca2+ gradients with subcellular organelles. J Cell Physiol 150:593-609.

White RE, Rao M, Gensel JC, McTigue DM, Kaspar BK, Jakeman LB. 2011. Transforming growth factor alpha transforms astrocytes to a growthsupportive phenotype after spinal cord injury. J Neurosci 31:15173-15187.

Young CC, van der Harg JM, Lewis NJ, Brooks KJ, Buchan AM, Szele FG. 2013. Ependymal ciliary dysfunction and reactive astrocytosis in a reorganized subventricular zone after stroke. Cereb Cortex 23:647-659.

Zhao C, Deng W, Gage FH. 2008. Mechanisms and functional implications of adult neurogenesis. Cell 132:645-660. 